\title{
Iodine-catalyzed Transformation of Aryl-substituted Alcohols Under Solvent-free and Highly Concentrated Reaction Conditions
}

\author{
Marjan Jereb $^{1, \star}$ and Dejan Vražič̌ \\ ${ }^{1}$ Chair of Organic Chemistry, Faculty of Chemistry and Chemical Technology, Večna pot 113, 1000 Ljubljana, Slovenia \\ ${ }^{2}$ Present address: Krka, d. d., Novo mesto, Šmarješka cesta 6, 8501 Novo mesto, Slovenia \\ *Corresponding author: E-mail: marjan.jereb@fkkt.uni-lj.si \\ Tel.: (++386) 14798577 Fax: (++386) 12419144
}

Received: 18-09-2017

Dedicated to Professor Emeritus Miha Tišler, University of Ljubljana, on the occasion of his $90^{\text {th }}$ birthday.

\begin{abstract}
Iodine-catalyzed transformations of alcohols under solvent-free reaction conditions (SFRC) and under highly concentrated reaction conditions (HCRC) in the presence of various solvents were studied in order to gain insight into the behavior of the reaction intermediates under these conditions. Dimerization, dehydration and substitution were the three types of transformations observed with benzylic alcohols. Dimerization and substitution reactions were predominant in the case of primary- and secondary alcohols, whereas dehydration prevailed in the case of tertiary alcohols. The relative reactivity of substituted 1-phenylethanols in $\mathrm{I}_{2}$-catalyzed dimerization under SFRC provided a good Hammett plot $\rho^{+}=$ $-2.8\left(r^{2}=0.98\right)$, suggesting the presence of electron-deficient intermediates with a certain degree of developed charge in the rate-determining step.
\end{abstract}

Keywords: Alcohols, catalysis, green chemistry, Hammett correlation, iodine

\section{Introduction}

Green chemistry is currently a popular topic in chemistry. Numerous serious efforts have been made to improve and simplify existing methods and procedures, especially in terms of atom-economy, process-efficiency, health, risk and waste-minimization..$^{1-3}$ Transformations of neat reactants under solvent-free reaction conditions (SFRC) are one of the best solutions in this regard. ${ }^{4-7}$ In the solid/solid system, a remarkable reaction rate enhancement was observed just by introducing small amounts of solvent vapor into the reaction mixture. ${ }^{8}$ Moreover, the course of the reaction can be dramatically influenced under highly concentrated reaction conditions (HCRC). ${ }^{9}$ It has been documented that water can remarkably affect the course of the reaction, ${ }^{10-12}$ including enantioselectivity. ${ }^{13-15}$ Water has become a reaction solvent of immense importance for the selectivity/reactivity studies of nucleophiles and electrophiles, ${ }^{16-18}$ where carbocation intermediates play an important role. ${ }^{19-21}$ Mixtures of water with organic solvents have been employed to determine the geometry of the transition states, ${ }^{22}$ with the hydrophobic effect attracting attention in studies of organic reactions in the presence of water. ${ }^{23-25}$ In recent years, iodine ${ }^{26,27}$ has emerged as remarkable catalyst exhibiting high water tolerance in diverse types of reactions. One of beneficial properties of iodine is its high affinity towards molecular oxygen as well as functional groups bearing at least one oxygen atom..$^{28,29}$ It has been established that iodine is an efficient catalyst for the transformation of alcohols under SFRC, with tertiary alcohols being dehydrated; ${ }^{30}$ while primary and secondary transformed into ethers or esters. ${ }^{31-33}$ This protocol has been already applied under various conditions ${ }^{34-36}$ all indicating participation of the reaction intermediates having a partial positive charge. Recently, important mechanistic studies on the iodine-catalyzed reactions in solution have been published, ${ }^{37,38}$ but the knowledge of the behavior of iodine under SFRC and HCRC remains largely undiscovered. ${ }^{39}$ 
The above reasons prompted us to investigate the reactivity of several model substrates in iodine-catalyzed transformations of alcohols under SFRC and HCRC. The alcohol substrates were selected to study different electronic effects and geometry. The role of the potentially present heteroatom and antiaromaticity of intermediates on transformations will be validated on sterically hindered dibenzo-substituted alcohols. Stereochemistry and regioselectivity of dehydration reactions and the role of the reaction medium polarity (protic vs. aprotic), nucleophilicity and $p \mathrm{~K}_{\mathrm{a}}$ under HCRC will be examined as well.

\section{Experimental}

\section{1. General}

1-Phenylethanol 1a, 1,1-diphenylethanol 1d and 4-methoxybenzyl alcohol $\mathbf{1 m}$ are commercially available, the other alcohols were prepared by various methods. A) Modified Grignard procedure, ${ }^{40}$ a typical experiment: under inert atmosphere, one crystal of iodine was added to magnesium turnings $(60 \mathrm{mmol})$ in $5 \mathrm{~mL}$ of dry THF, and a few drops of the corresponding halogenide $\left(\mathrm{PhCH}_{2} \mathrm{Cl}\right.$, $\mathrm{PhBr}$ or EtI) $(60 \mathrm{mmol})$. The rest of the halogenide was diluted with $25 \mathrm{~mL}$ of dry THF and slowly added at room temperature. The reaction mixture was refluxed for 90 minutes, then cooled to room temperature, diluted with 50 $\mathrm{mL}$ of dry THF and a solution of the appropriate carbonyl molecule (PhCOMe, $\mathrm{Ph}_{2} \mathrm{CO}, 4$ '-methoxyacetophenone, 2'-methoxyacetophenone, 4-methoxybenzaldehyde, 4',4'dimethoxybenzophenone or 9-fluorenone) (20 mmol) in $50 \mathrm{~mL}$ of dry THF was slowly added and the reaction mixture was refluxed for two hours. After cooling, THF was evaporated and the reaction mixture diluted with $\mathrm{Et}_{2} \mathrm{O}$ and water. The organic phase was separated, washed with water, dried over anhydrous $\mathrm{Na}_{2} \mathrm{SO}_{4}$; the solvent evaporated and pure products were obtained after column chromatography or crystallization. Alcohols prepared by method A: 1,2-diphenyl-2-propanol ${ }^{41}$ 1c, 1,1-diphenyl-1-propanol ${ }^{42}$ 1e, 1-(4-methoxyphenyl)-2-phenylethanol ${ }^{43}$ 1i, 1-(4-methoxyphenyl)-1-phenylethanol ${ }^{44} \mathbf{1 j}, 1$-(2-methoxyphenyl)1-phenylethanol ${ }^{45} \mathbf{1 k}, 1,1$-bis(4-methoxyphenyl)-2-phenylethanol $^{46}$ 1l, 2-(4-methoxyphenyl)-1-phenyl-2-propanol $^{47}$ 1n, 9-ethyl-9-fluorenol ${ }^{48} 4 a$, 9-benzyl-9-fluorenol ${ }^{49}$ 4b and 9-benzyl-9-xanthenol ${ }^{50}$ 4f. B) $\mathrm{Na} / \mathrm{RX} /$ carbonyl molecule, a typical experiment: xanthone or dibenzosuberone $(20 \mathrm{mmol})$ was dissolved in toluene $(40 \mathrm{~mL})$, followed by the addition of ethyl iodide or benzyl chloride ( 60 $\mathrm{mmol}$ ) and sodium $(120 \mathrm{mmol})$. The reaction mixture was refluxed for one hour, cooled to room temperature, diluted with toluene; water was added in small portions. The organic phase was separated, washed with water, dried over anhydrous $\mathrm{Na}_{2} \mathrm{SO}_{4}$ and the solvent removed under reduced pressure. Alcohols prepared by method B: 5-ethyl-10,11-dihydro-5H-dibenzo[a,d]cyclohepten-5-ol 4c, 9-ethyl-9$x^{x a n t h e n o l}{ }^{51} 4 \mathbf{e}$, and 5-benzyl-10,11-dihydro-5H-diben- zo[a,d]cyclohepten-5-ol 4d. C) By reduction of commercially available ketones with $\mathrm{NaBH}_{4}$ : 1,2-diphenylethanol ${ }^{41}$ 1b, 1-(4-methoxyphenyl)ethanol ${ }^{52}$ 1h, 1-(4-fluorophenyl) ethanol ${ }^{52}$ 1o, 1-(3-methylphenyl)ethanol ${ }^{52} \mathbf{1 p}, 1-(3-$ methoxyphenyl)ethanol ${ }^{52} \mathbf{1 q}, 1$-(4-chlorophenyl)ethanol ${ }^{52} \mathbf{1 r}$, 1-(4-bromophenyl)ethanol ${ }^{52}$ 1s. D) By reduction using Al$\mathrm{KOH}:{ }^{53}$ Xanthydrol ${ }^{54}$ 10. E) By halohydroxylation: ${ }^{55,56}$ 1,1-diphenyl-2-bromoethano ${ }^{57}$ 1f and 1,1-diphenyl-2-fluoroethanol ${ }^{58} \mathbf{1 g}$. Pure products were usually obtained using column chromatography (CC) at given conditions using Fluka 60 silica gel $(63-200 \mu \mathrm{m}, 70-230$ mesh ASTM). Reaction progress was monitored by thin-layer chromatography on Merck $60 \mathrm{~F}_{254}$ TLC plates or by ${ }^{1} \mathrm{H}$ NMR spectroscopy. NMR spectra were recorded on Bruker Avance 300 DPX, and Bruker Avance III 500 Instrument $\left({ }^{1} \mathrm{H}: 300\right.$ $\mathrm{MHz},{ }^{13} \mathrm{C}: 75.5 \mathrm{MHz}$ and $\left.125 \mathrm{MHz}\right)$. The ${ }^{1} \mathrm{H}$ spectra were referred to an internal standard (0 ppm for TMS) or to the residual ${ }^{1} \mathrm{H}$ signal of $\mathrm{CHCl}_{3}$ at $7.26 \mathrm{ppm}$. The ${ }^{13} \mathrm{C}$ spectra were referred to the central line of $\mathrm{CDCl}_{3}(77.00 \mathrm{ppm})$. New compounds were characterized by ${ }^{1} \mathrm{H}$ NMR, ${ }^{13} \mathrm{C}$ NMR and IR spectroscopy, HRMS and/or elemental analysis, and also with the melting points when solid. Known products were characterized by ${ }^{1} \mathrm{H}$ NMR and IR spectroscopy, melting point when solid and by LRMS in most of the cases. Additionally, ${ }^{13} \mathrm{C}$ NMR spectra were recorded for those products, whose ${ }^{13} \mathrm{C}$ NMR data were not found in the literature. Melting points were determined on Büchi 535 apparatus and are not corrected. Mass spectra were obtained with the electron ionization (EI). Elemental combustion analyses were performed on Perkin-Elmer analyser $2400 \mathrm{CHN}$.

\section{2. General Procedure for Iodine-catalyzed Transformation of Alcohols Under SFRC}

The procedure is the same for solid and liquid substrates. Alcohol $(1 \mathrm{mmol})$ and iodine $(3 \mathrm{~mol} \%)$ were mixed together in a $5 \mathrm{~mL}$ conical reactor and the reaction mixture stirred at $25^{\circ} \mathrm{C}$ or $55^{\circ} \mathrm{C}$ for various times $(5 \mathrm{~min}$ to $192 \mathrm{~h}$ ), progress was monitored by TLC or by ${ }^{1} \mathrm{H}$ NMR spectroscopy. The crude reaction mixture was diluted with tert-butyl methyl ether, washed with an aqueous solution of $\mathrm{Na}_{2} \mathrm{~S}_{2} \mathrm{O}_{3}$, water, dried over $\mathrm{Na}_{2} \mathrm{SO}_{4}$ and the solvent evaporated under reduced pressure. The crude reaction mixture was subjected to column chromatography or preparative TLC using hexane or petroleum ether/tert-butyl methyl ether mixtures and pure product(s) were obtained. Conversions were determined by ${ }^{1} \mathrm{H}$ NMR spectroscopy. The effects of reaction variables on the type of transformation and conversions are stated in Tables and Figures. In order to obtain the information (role) of the reaction variables and structure of substrate, the data (reaction times with lower conversion) are presented in some Tables. In the experimental section, the best reaction conditions are named; $3 \mathrm{~mol} \%$ of $\mathrm{I}_{2}$ were used, giving the highest yield. 


\section{3. General Procedure for Iodine-catalyzed Transformation of Alcohols Under HCRC}

The procedure is the same for solid and liquid substrates. To the mixture of alcohol $(1 \mathrm{mmol})$ and various amounts of solvent $\left(\mathrm{CH}_{2} \mathrm{Cl}_{2}, \mathrm{MeOH}\right.$, EtOH, $i-\mathrm{PrOH}$, TFE, HFIP, $\mathrm{HCOOH}, \mathrm{AcOH}$ and $\mathrm{H}_{2} \mathrm{O} 3-300 \mathrm{mmol}$ ) iodine (3 mol\%) was added in $5 \mathrm{~mL}$ conical reactor and the reaction mixture stirred at $25{ }^{\circ} \mathrm{C}$ from five minutes to 360 hours. Isolation and purification procedure was the same as described above. Conversions were determined by ${ }^{1} \mathrm{H}$ NMR spectroscopy. Results are presented in Tables, Figures and Schemes. Isolation procedure is given for the best yield.

\section{4. Determination of Hammett Reaction Constant $\rho^{+}$for the $I_{2}$-catalyzed Dimerization of 1-phenylethanols}

1-phenylethanols ( $0.5 \mathrm{mmol})$ (1a, 1o, 1p, 1q, 1r, 1s) were separately placed in the conical reactors, transformation was induced by iodine ( $0.015 \mathrm{mmol}, 3.8 \mathrm{mg}, 3 \mathrm{~mol} \%)$ at $55{ }^{\circ} \mathrm{C}$. Alcohols $1 \mathbf{0}$ and $\mathbf{1 p}$ were stirred for two hours, and alcohols 1q, $1 \mathbf{r}$ and $1 \mathbf{s}$ were stirred for three hours. The transformation was stopped by cooling, the reaction mixture was analyzed by ${ }^{1} \mathrm{H}$ NMR spectroscopy and relative rate constants calculated from the equation ${ }^{59} k_{r}=k_{A} / k_{B}=$ $\log ((A-X) / A) / \log ((B-Y) / B)$, derived from the Ingold-Shaw relation ${ }^{60}$ where $A$ and $B$ are the amounts of starting material and $X$ and $Y$ the amounts of products derived from them. The relative rate factors thus obtained, collected in Figure 1, are the averages of at least two measurements, giving a good reproducibility, deviation of $k_{\text {rel }}$ ranged $( \pm 3 \%)$. The reaction of reference substrate 1-phenylethanol 1a was quenched separately after $2 \mathrm{~h}$ and $3 \mathrm{~h}$ and relative rate constants were obtained by means of ${ }^{1} \mathrm{H}$ NMR spectroscopy utilising internal standard 1,1-diphenylethene.

\section{5. Volumetric Determination of Iodine After the $\mathrm{I}_{2}$-catalyzed Reaction of $1 \mathrm{n}$ Under HCRC in $\mathrm{MeOH}$}

To a mixture of 1-(4-methoxyphenyl)-2-phenylethan-1-ol 1n (1 mmol, $228 \mathrm{mg})$ and methanol (3 mmol, $96 \mathrm{mg}$ ) iodine ( $0.03 \mathrm{mmol}, 7.6 \mathrm{mg}$ ) was added and the mixture stirred for 30 minutes at $25^{\circ} \mathrm{C}$. A reaction mixture was diluted with acetonitrile $(5 \mathrm{~mL})$ and titrated with a standard solution of $\mathrm{Na}_{2} \mathrm{~S}_{2} \mathrm{O}_{3}(\mathrm{c}=0.1022 \mathrm{~mol} / \mathrm{L}, \mathrm{V}=0.58 \mathrm{~mL})$.

\section{6. Volumetric Determination of Iodine After the $\mathrm{I}_{2}$-catalyzed Reaction of $1 \mathrm{n}$ Under HCRC in $\mathrm{CH}_{2} \mathrm{Cl}_{2}$}

To a mixture of 1-(4-methoxyphenyl)-2-phenylethan-1-ol $1 \mathbf{n}(1 \mathrm{mmol}, 228 \mathrm{mg})$ and dichloromethane (3 mmol, $255 \mathrm{mg}$ ) iodine $(0.03 \mathrm{mmol}, 7.6 \mathrm{mg})$ was added and the mixture stirred for 30 minutes at $25{ }^{\circ} \mathrm{C}$. A reaction mixture was diluted with acetonitrile $(5 \mathrm{~mL})$ and titrated with a standard solution of $\mathrm{Na}_{2} \mathrm{~S}_{2} \mathrm{O}_{3}(\mathrm{c}=0.1022 \mathrm{~mol} / \mathrm{L}, \mathrm{V}=$ $0.57 \mathrm{~mL})$.

\section{7. Spectroscopic and Analytical Data of Novel Compounds}

Bis[1-(4-fluorophenyl)ethyl] ether 2o

SFRC (r.t. $\left.=4.5 \mathrm{~h}, 55{ }^{\circ} \mathrm{C}\right), \mathrm{CC}\left(\mathrm{SiO}_{2}\right.$, petroleum ether), colorless oil (90\%), as a mixture of stereoisomers in ratio 1/0.39; IR (neat): 2976, 2930, 1604, 1508, 1371, 1224, $1156,1091,949,836 \mathrm{~cm}^{-1} ;{ }^{1} \mathrm{H}$ NMR $\left(300 \mathrm{MHz}, \mathrm{CDCl}_{3}\right): \delta$ $7.23-7.12(\mathrm{~m}, 8 \mathrm{H}), 7.05-6.87(\mathrm{~m}, 8 \mathrm{H}), 4.42(\mathrm{q}, J=6.4 \mathrm{~Hz}$, $2 \mathrm{H}), 4.13(\mathrm{q}, J=6.5 \mathrm{~Hz}, 2 \mathrm{H}$, major), $1.41(\mathrm{~d}, J=6.4 \mathrm{~Hz}$, $6 \mathrm{H}), 1.32$ (d, $J=6.5 \mathrm{~Hz}, 6 \mathrm{H}$, major); ${ }^{13} \mathrm{C}$ NMR $(75.5 \mathrm{MHz}$, $\left.\mathrm{CDCl}_{3}\right): \delta 162.2(\mathrm{~d}, J=245 \mathrm{~Hz}, 2 \mathrm{C}$, major), $162.0(\mathrm{~d}, J=$ $245 \mathrm{~Hz}, 2 \mathrm{C}$, minor), 139.8 (d, $J=3 \mathrm{~Hz}, 2 \mathrm{C}$, minor), 139.6 (d, $J=3 \mathrm{~Hz}, 2 \mathrm{C}$, major), $127.8(\mathrm{~d}, J=8 \mathrm{~Hz}, 4 \mathrm{C}$, major), 127.7 (d, $J=8 \mathrm{~Hz}, 4 \mathrm{C}$, minor), 115.3 (d, $J=22 \mathrm{~Hz}, 4 \mathrm{C}$, major), 115.0 (d, $J=22 \mathrm{~Hz}, 4 \mathrm{C}$, minor), 74.1 (minor), 73.9 (major), 24.7 (major), 23.1 (minor); $\mathrm{MS} m / z$ (EI): $262\left(\mathrm{M}^{+}\right.$, $<1 \%), 247$ (4), 123 (100), 103 (20); HRMS: Calcd for $\mathrm{C}_{16} \mathrm{H}_{16} \mathrm{~F}_{2} \mathrm{O} 262.1169$; found 262.1172.

\section{Bis[1-(3-methylphenyl)ethyl] ether 2p}

SFRC (r.t. $\left.=4.5 \mathrm{~h}, 55^{\circ} \mathrm{C}\right)$, $\mathrm{CC}\left(\mathrm{SiO}_{2}\right.$, hexane $/ \mathrm{CH}_{2 \text { - }}$ $\mathrm{Cl}_{2}$ ), colorless oil (87\%), as a mixture of stereoisomers in ratio 1/0.37; IR (neat): 2973, 2924, 1607, 1487, 1447, 1368, 1160, 1092, 1034, 786, $705 \mathrm{~cm}^{-1}$; ${ }^{1} \mathrm{H}$ NMR $(300$ $\left.\mathrm{MHz}, \mathrm{CDCl}_{3}\right): \delta 7.22-6.93(\mathrm{~m}, 16 \mathrm{H}), 4.42(\mathrm{q}, J=6.4 \mathrm{~Hz}$, $2 \mathrm{H}), 4.14$ (q, $J=6.5 \mathrm{~Hz}, 2 \mathrm{H}$, major), 2.36 (s, 6H, major), 2.30 (s, 6H, minor), 1.41 (d, $J=6.4 \mathrm{~Hz}, 6 \mathrm{H}$, minor), 1.32 (d, $J=6.5 \mathrm{~Hz}, 6 \mathrm{H}$, major); ${ }^{13} \mathrm{C} \mathrm{NMR}\left(75.5 \mathrm{MHz}, \mathrm{CDCl}_{3}\right)$ : $\delta 144.2,144.2,137.9,137.7,128.3,128.1,128.1,127.8$, $127.0,126.9,123.3,123.3,74.6$ (major), 74.4 (minor), 24.7 (major), 22.9 (minor), 21.5 (major), 21.4 (minor); MS m/z (EI): $254\left(\mathrm{M}^{+},<1 \%\right), 135$ (23), 119 (100), 105 (13), 91 (16); HRMS: Calcd for $\mathrm{C}_{18} \mathrm{H}_{22} \mathrm{O} 254.1671$; found 254.1677. Anal. Calcd for $\mathrm{C}_{18} \mathrm{H}_{22} \mathrm{O}$ : C, 84.99; H, 8.72. Found: C, 84.65; H, 9.03.

\section{Bis[1-(4-bromophenyl)ethyl] ether 2s}

SFRC (r.t. $\left.=18 \mathrm{~h}, 55^{\circ} \mathrm{C}\right), \mathrm{CC}\left(\mathrm{SiO}_{2}\right.$, hexane), white solid $(81 \%)$, as a mixture of stereoisomers in ratio $1 / 0.53$; mp 68-74 ${ }^{\circ} \mathrm{C}$; IR (neat): $\mathrm{cm}^{-1} ;{ }^{1} \mathrm{H}$ NMR $\left(300 \mathrm{MHz}, \mathrm{CDCl}_{3}\right.$ ): $\delta 7.45(\mathrm{~d}, J=8.4 \mathrm{~Hz}, 4 \mathrm{H}), 7.38(\mathrm{~d}, J=8.4 \mathrm{~Hz}, 4 \mathrm{H}), 7.11(\mathrm{~d}$, $J=8.4 \mathrm{~Hz}, 4 \mathrm{H}), 7.09(\mathrm{~d}, J=8.4 \mathrm{~Hz}, 4 \mathrm{H}), 4.42(\mathrm{q}, J=6.4 \mathrm{~Hz}$, $2 \mathrm{H}$, minor), $4.13(\mathrm{q}, J=6.5 \mathrm{~Hz}, 2 \mathrm{H}$, major), $1.41(\mathrm{~d}, J=6.4$ $\mathrm{Hz}, 6 \mathrm{H}$, minor), 1.32 (d, $J=6.5 \mathrm{~Hz}, 6 \mathrm{H}$, major); ${ }^{13} \mathrm{C}$ NMR $\left(75.5 \mathrm{MHz}, \mathrm{CDCl}_{3}\right): \delta 143.1,142.9,131.7,131.4,128.0$, 127.9, 121.3, 121.0, 74.2, 74.2, 24.5 (major), 23.0 (minor); MS $m / z(\mathrm{EI}): 382\left(\mathrm{M}^{+}, 2 \%\right), 367$ (5), 226 (6), 199 (21), 185 (100), 104 (35); HRMS: Calcd for $\mathrm{C}_{16} \mathrm{H}_{16} \mathrm{Br}_{2} \mathrm{O} 381.9568$; found 381.9578 . 
5-Ethyl-10,11-dihydro-5H-dibenzo[a,d]cyclohepten-5ol 4c

(20 mmol (4.17 g) dibenzosuberone, $120 \mathrm{mmol}(2.76$ g) Na, $60 \mathrm{mmol}(9.36 \mathrm{~g})$ EtI, $40 \mathrm{~mL}$ toluene, $1 \mathrm{~h}$, reflux), $\mathrm{CC}\left(\mathrm{SiO}_{2}, \mathrm{CH}_{2} \mathrm{Cl}_{2} /\right.$ petroleum ether, 1/4) and crystallization (petroleum ether), white solid (82\%); mp 61.0-62.0 ${ }^{\circ} \mathrm{C}$; IR (KBr): 3400, 2932, 1485, 1455, 1317, 1080, 1041, 965, 924, 889, $750 \mathrm{~cm}^{-1}$; ${ }^{1} \mathrm{H}$ NMR $\left(300 \mathrm{MHz}, \mathrm{CDCl}_{3}\right): \delta$ 7.91-7.88 (m, 2H), 7.26-7.08 (m, 6H), 3.41-3.31 (m, 2H), $3.01-2.91(\mathrm{~m}, 2 \mathrm{H}), 2.23(\mathrm{q}, J=7.4 \mathrm{~Hz}, 2 \mathrm{H}), 2.14(\mathrm{~s}, 1 \mathrm{H})$, $0.69(\mathrm{t}, J=7.4 \mathrm{~Hz}, 3 \mathrm{H}) ;{ }^{13} \mathrm{C}$ NMR $\left(75.5 \mathrm{MHz}, \mathrm{CDCl}_{3}\right): \delta$ 144.6, 138.8, 130.2, 127.2, 127.1, 126.1, 79.4, 38.2, 34.6, 8.8; MS $m / z$ (EI): 237 ( $\left.\mathrm{M}^{+}-\mathrm{H}, 2 \%\right), 220$ (1), 209 (100), 131 (26), 103 (26), 91 (15); Anal. Calcd for $\mathrm{C}_{17} \mathrm{H}_{18} \mathrm{O}: \mathrm{C}, 85.67$; H, 7.61. Found: C, 85.88; $\mathrm{H}, 7.83$.

\section{5-Benzyl-10,11-dihydro-5H-dibenzo[a,d]cyclohepten- 5-ol 4d}

(20 mmol (4.17 g) dibenzosuberone, $120 \mathrm{mmol}$ (2.76 g) $\mathrm{Na}, 60 \mathrm{mmol}(7.59 \mathrm{~g}) \mathrm{PhCH}_{2} \mathrm{Cl}, 40 \mathrm{~mL}$ toluene, $1 \mathrm{~h}$, reflux), $\mathrm{CC}\left(\mathrm{SiO}_{2}, \mathrm{CH}_{2} \mathrm{Cl}_{2} /\right.$ petroleum ether, 1/4) and crystallization (petroleum ether), white solid (85\%); mp 61.6$63.7^{\circ} \mathrm{C}$; IR (KBr): $3468,2924,1599,1486,1450,1275$, 1077, 1012, 766, 700, $673 \mathrm{~cm}^{-1}$; ${ }^{1} \mathrm{H}$ NMR $(300 \mathrm{MHz}$, $\left.\mathrm{CDCl}_{3}\right): \delta 7.73-7.70(\mathrm{~m}, 2 \mathrm{H}), 7.19-7.04(\mathrm{~m}, 9 \mathrm{H}), 6.73-6.70$ $(\mathrm{m}, 2 \mathrm{H}), 3.47(\mathrm{~s}, 2 \mathrm{H}), 3.46-3.37(\mathrm{~m}, 2 \mathrm{H}), 3.07-2.97(\mathrm{~m}$, 2H), $2.32(\mathrm{~s}, 1 \mathrm{H}) ;{ }^{13} \mathrm{C}$ NMR $\left(75.5 \mathrm{MHz}, \mathrm{CDCl}_{3}\right): \delta 143.9$, $139.1,136.2,130.7,130.0,127.7,127.6,127.3,126.5,126.2$, 79.1, 51.9, 35.1; MS $m / z$ (EI): $300\left(\mathrm{M}^{+}-\mathrm{H}, 1 \%\right), 282(<1)$, 209 (100), 131 (49), 103 (19), 91 (27); Anal. Calcd for $\mathrm{C}_{22} \mathrm{H}_{20} \mathrm{O}: \mathrm{C}, 87.96 ; \mathrm{H}, 6.71$. Found: C, 87.84; H, 6.83.

\section{2-Methoxy-2-(4-methoxyphenyl)-1-phenylpropane 6na}

HCRC $\left(\mathrm{MeOH}\right.$, r.t. $\left.=4 \mathrm{~h}, 25^{\circ} \mathrm{C}\right)$, $\mathrm{CC}\left(\mathrm{SiO}_{2}\right.$, petroleum ether), colorless viscous oil (39\%); IR (neat): 2937 , 2824, 1610, 1510, 1455, 1371, 1299, 1249, 1088, 832, 701 $\mathrm{cm}^{-1} ;{ }^{1} \mathrm{H}$ NMR $\left(300 \mathrm{MHz}, \mathrm{CDCl}_{3}\right): \delta 7.18-7.13(\mathrm{~m}, 5 \mathrm{H})$, 6.87-6.82 (m, 4H), $3.81(\mathrm{~s}, 3 \mathrm{H}), 3.08(\mathrm{~s}, 3 \mathrm{H}), 3.02(\mathrm{~d}, J=$ $13.1 \mathrm{~Hz}, 1 \mathrm{H}), 2.95(\mathrm{~d}, J=13.1 \mathrm{~Hz}, 1 \mathrm{H}), 1.46(\mathrm{~s}, 3 \mathrm{H}) ;{ }^{13} \mathrm{C}$ NMR $\left(75.5 \mathrm{MHz}, \mathrm{CDCl}_{3}\right): \delta 158.5,137.6,136.2,130.7$, $127.9,127.5,126.0,113.2,79.5,55.2,50.7,50.3,21.3$; MS $m / z$ (EI): $224\left(\mathrm{M}^{+}-\mathrm{MeOH}, 88 \%\right), 209$ (20), 165 (56), 133 (100), 128 (18). Anal. Calcd for $\mathrm{C}_{17} \mathrm{H}_{20} \mathrm{O}_{2}$ : C, 79.65; H, 7.86. Found: C, 79.22; H, 7.87.

\section{2-Ethoxy-2-(4-methoxyphenyl)-1-phenylpropane 6nb}

$\left(\mathrm{EtOH}, 30 \mathrm{mmol}\right.$, r.t. $\left.=19 \mathrm{~h}, 25^{\circ} \mathrm{C}\right), \mathrm{CC}\left(\mathrm{SiO}_{2}\right.$, petroleum ether), viscous colorless oil (73\%); IR (neat): 2975 , $1609,1510,1454,1300,1250,1179,1091,1034,833,702$ $\mathrm{cm}^{-1} ;{ }^{1} \mathrm{H}$ NMR $\left(300 \mathrm{MHz}, \mathrm{CDCl}_{3}\right): \delta 7.13-7.07(\mathrm{~m}, 5 \mathrm{H})$, 6.83-6.80 (m, 2H), $6.75(\mathrm{~d}, J=8.8 \mathrm{~Hz}, 2 \mathrm{H}), 3.79(\mathrm{~s}, 3 \mathrm{H})$, $3.30(\mathrm{dq}, J=14.2 \mathrm{~Hz}, J=7.0 \mathrm{~Hz}, 1 \mathrm{H}), 3.09(\mathrm{dq}, J=14.2 \mathrm{~Hz}$, $J=7.0 \mathrm{~Hz}, 1 \mathrm{H}), 2.96(\mathrm{~d}, J=13.1 \mathrm{~Hz}, 1 \mathrm{H}), 2.87(\mathrm{~d}, J=13.1$ $\mathrm{Hz}, 1 \mathrm{H}), 1.43(\mathrm{~s}, 3 \mathrm{H}), 1.16(\mathrm{t}, J=7.0 \mathrm{~Hz}, 3 \mathrm{H}) ;{ }^{13} \mathrm{C} \mathrm{NMR}$ $\left(75.5 \mathrm{MHz}, \mathrm{CDCl}_{3}\right): \delta 158.4,137.7,137.0,130.8,127.7$, $127.4,126.0,113.2,79.1,57.6,55.2,51.0,21.8,15.8$; MS $m / z$ (EI): 225 (M+ $\mathrm{M}^{+}$OEt, 5\%), 179 (100), 151 (41). Anal. Calcd for $\mathrm{C}_{18} \mathrm{H}_{22} \mathrm{O}_{2}$ : C, 79.96; H, 8.20. Found: C, 79.75; H, 8.56 .

\section{1,2-Diphenylethyl formate $7 \mathrm{ba}$}

$\mathrm{HCRC}\left(\mathrm{HCOOH}\right.$, without $\mathrm{I}_{2}$, r.t. $\left.=23 \mathrm{~h}, 25^{\circ} \mathrm{C}\right)$, CC $\left(\mathrm{SiO}_{2}\right.$, petroleum ether), viscous colorless oil (81\%); IR (neat): 3064, 3031, 2925, 1724, 1495, 1450, 1167, 755, 699 $\mathrm{cm}^{-1} ;{ }^{1} \mathrm{H}$ NMR $\left(300 \mathrm{MHz}, \mathrm{CDCl}_{3}\right): \delta 7.99(\mathrm{~s}, 1 \mathrm{H}), 7.32$ $7.16(\mathrm{~m}, 8 \mathrm{H}), 7.07-7.04(\mathrm{~m}, 2 \mathrm{H}), 6.02(\mathrm{dd}, J=7.7 \mathrm{~Hz}, J=$ $6.2 \mathrm{~Hz}, 1 \mathrm{H}), 3.21(\mathrm{dd}, J=13.8 \mathrm{~Hz}, J=7.7 \mathrm{~Hz}, 1 \mathrm{H}), 3.06(\mathrm{dd}$, $J=13.8 \mathrm{~Hz}, J=6.2 \mathrm{~Hz}, 1 \mathrm{H}) ;{ }^{13} \mathrm{C} \mathrm{NMR}\left(75.5 \mathrm{MHz}, \mathrm{CDCl}_{3}\right)$ : $\delta 160.1,139.3,136.6,129.5,128.4,128.3,128.2,126.7$, 126.6, 76.5, 42.8; MS $m / z$ (EI): $180\left(\mathrm{M}^{+}-\mathrm{HCOOH}, 61 \%\right)$, 135 (50), 107 (100), 91 (44), 79 (86), 77 (50). Anal. Calcd for $\mathrm{C}_{15} \mathrm{H}_{14} \mathrm{O}_{2}$ : C, 79.62; H, 6.24. Found: C, 79.66; H, 6.27.

\section{1-(4-Methoxyphenyl)-2-phenylethyl formate 7ia}

$\mathrm{HCRC}\left(\mathrm{HCOOH}\right.$, without $\mathrm{I}_{2}$, r.t. $\left.=30 \mathrm{~min}, 25^{\circ} \mathrm{C}\right)$, preparative chromatography $\left(\mathrm{SiO}_{2}, \mathrm{CH}_{2} \mathrm{Cl}_{2}\right)$, white solid (55\%); mp 63.0-63.8 ${ }^{\circ} \mathrm{C}$; IR (KBr): 2910, 2837, 1710, 1512, 1242, 1163, 1035, 977, 831, 734, $698 \mathrm{~cm}^{-1}$; ${ }^{1} \mathrm{H}$ NMR (300 $\left.\mathrm{MHz}, \mathrm{CDCl}_{3}\right): \delta 8.01(\mathrm{~s}, 1 \mathrm{H}), 7.28-7.18(\mathrm{~m}, 5 \mathrm{H}), 7.14-7.08$ $(\mathrm{m}, 2 \mathrm{H}), 6.85(\mathrm{~d}, J=8.8 \mathrm{~Hz}, 2 \mathrm{H}), 6.02(\mathrm{dd}, J=7.8 \mathrm{~Hz}, J=$ $6.2 \mathrm{~Hz}, 1 \mathrm{H}), 3.80(\mathrm{~s}, 3 \mathrm{H}), 3.24(\mathrm{dd}, J=13.8 \mathrm{~Hz}, J=7.8 \mathrm{~Hz}$, $1 \mathrm{H}), 2.82(\mathrm{dd}, J=13.8 \mathrm{~Hz}, J=6.2 \mathrm{~Hz}, 1 \mathrm{H}) ;{ }^{13} \mathrm{C} \mathrm{NMR}(75.5$ $\left.\mathrm{MHz}, \mathrm{CDCl}_{3}\right): \delta 160.2,159.5,136.7,131.4,129.5,128.3$, 128.1, 126.6, 113.8, 76.3, 55.2, 42.6; MS $m / z(\mathrm{EI}): 256\left(\mathrm{M}^{+}\right.$, 3\%), 211 (10), 165 (91), 137 (100), 109 (20), 69 (27); HRMS: Calcd for $\mathrm{C}_{16} \mathrm{H}_{16} \mathrm{O}_{3}$ 256.1099; found 256.1102. Anal. Calcd for $\mathrm{C}_{16} \mathrm{H}_{16} \mathrm{O}_{3}$ : C, 74.98; H, 6.29. Found: C, $74.71 ; \mathrm{H}, 6.27$.

\section{(E)-1,5-Diphenyl-4-methyl-2,4-di(4-methoxyphenyl) pent-1-ene 9a}

SFRC (r.t. $=30 \mathrm{~min}, 25^{\circ} \mathrm{C}$ ), CC and separation by preparative chromatography $\left(\mathrm{SiO}_{2}\right.$, petroleum ether/t-butyl methyl ether $=97.5 / 2.5)$, white solid $(23 \%), \mathrm{mp} 92.7-$ $94.6{ }^{\circ} \mathrm{C}$; IR (KBr): 2932, 2834, 1607, 1510, 1454, 1290, $1248,1180,1034,824,699 \mathrm{~cm}^{-1}$; ${ }^{1} \mathrm{H}$ NMR $(300 \mathrm{MHz}$, $\left.\mathrm{CDCl}_{3}\right): \delta 7.31-7.19(\mathrm{~m}, 3 \mathrm{H}), 7.16-7.10(\mathrm{~m}, 4 \mathrm{H}), 7.05-6.97$ $(\mathrm{m}, 3 \mathrm{H}), 6.87(\mathrm{~d}, J=8.8 \mathrm{~Hz}, 2 \mathrm{H}), 6.74(\mathrm{~d}, J=8.8 \mathrm{~Hz}, 2 \mathrm{H})$, 6.67-6.57 (m, 4H), $6.54(\mathrm{~s}, 1 \mathrm{H}), 3.78(\mathrm{~s}, 3 \mathrm{H}), 3.75(\mathrm{~s}, 3 \mathrm{H})$, $3.24(\mathrm{~d}, J=13.9 \mathrm{~Hz}, 1 \mathrm{H}), 3.17(\mathrm{~d}, J=13.9 \mathrm{~Hz}, 1 \mathrm{H}), 2.83(\mathrm{~d}$, $J=13.1 \mathrm{~Hz}, 1 \mathrm{H}), 2.66(\mathrm{~d}, J=13.1 \mathrm{~Hz}, 1 \mathrm{H}), 0.92(\mathrm{~s}, 3 \mathrm{H}) ;{ }^{13} \mathrm{C}$ NMR $\left(75.5 \mathrm{MHz}, \mathrm{CDCl}_{3}\right): \delta 158.4,157.2,141.0,138.9$, $138.6,137.6,131.4,130.5,128.9,128.2,128.1,128.0,127.3$, 126.2, 125.7, 113.3, 112.8, 55.2, 55.1, 50.0, 43.0, 42.8, 23.3; MS $m / z$ (EI): $448\left(\mathrm{M}^{+},<1 \%\right), 357(<2), 225$ (100), 91 (15). Anal. Calcd for $\mathrm{C}_{32} \mathrm{H}_{32} \mathrm{O}_{2}: \mathrm{C}, 85.68 ; \mathrm{H}, 7.19$. Found: C, 85.37; H, 7.38 .

\section{(Z)-1,5-Diphenyl-4-methyl-2,4-di(4-methoxyphenyl) pent-1-ene $9 b$ \\ SFRC (r.t. $=30 \mathrm{~min}, 25^{\circ} \mathrm{C}$ ), $\mathrm{CC}$ and separation by preparative chromatography $\left(\mathrm{SiO}_{2}\right.$, petroleum ether/t-}


butyl methyl ether $=97.5 / 2.5)$, white solid $(29 \%), \mathrm{mp}$ 74.6-75.5 ${ }^{\circ} \mathrm{C}$; IR (KBr): 2930, 2834, 1607, 1510, 1454, 1288, 1247, 1180,1033,826, $699 \mathrm{~cm}^{-1}$; ${ }^{1} \mathrm{H}$ NMR (300 $\left.\mathrm{MHz}, \mathrm{CDCl}_{3}\right): \delta 7.08-6.99(\mathrm{~m}, 8 \mathrm{H}), 6.85-6.63(\mathrm{~m}, 9 \mathrm{H})$, $6.15(\mathrm{~s}, 1 \mathrm{H}), 3.78(\mathrm{~s}, 3 \mathrm{H}), 3.75(\mathrm{~s}, 3 \mathrm{H}), 3.06(\mathrm{~d}, J=13.1$ $\mathrm{Hz}, 1 \mathrm{H}), 3.02(\mathrm{~d}, J=13.1 \mathrm{~Hz}, 1 \mathrm{H}), 2.85(\mathrm{~d}, J=13.1 \mathrm{~Hz}$, $1 \mathrm{H}), 2.78(\mathrm{~d}, J=13.1 \mathrm{~Hz}, 1 \mathrm{H}), 1.12(\mathrm{~s}, 3 \mathrm{H}) ;{ }^{13} \mathrm{C} \mathrm{NMR}$ $\left(75.5 \mathrm{MHz}, \mathrm{CDCl}_{3}\right): \delta 158.1,157.3,139.6,138.6,138.4$, $137.7,134.3,130.5,130.0,128.9,128.2,127.7,127.3$, $125.9,125.8,113.5,112.9,55.2,55.1,53.6,50.4,42.9$, 23.3; MS $m / z$ (EI): $448\left(\mathrm{M}^{+},<1 \%\right), 357$ (1), 225 (100), 91
(17). Anal. Calcd for $\mathrm{C}_{32} \mathrm{H}_{32} \mathrm{O}_{2}: \mathrm{C}, 85.68 ; \mathrm{H}, 7.19$. Found: C, 85.52; H, 7.44.

\section{Results and Discussion}

Most of the published $\mathrm{I}_{2}$-catalyzed transformations of alcohols were conducted in relatively diluted solution, in a concentration range of $23 \mathrm{~mol}$ to $157 \mathrm{~mol}$ of solvent per mol of alcohol. ${ }^{61,62}$ In contrast, we examined the behavior of substituted benzylic alcohols in highly-concentrated

Table 1. The effect of the alcohol structure $\mathbf{1}$ and reaction conditions (SFRC vs. HCRC) on the type of iodine-induced transformation

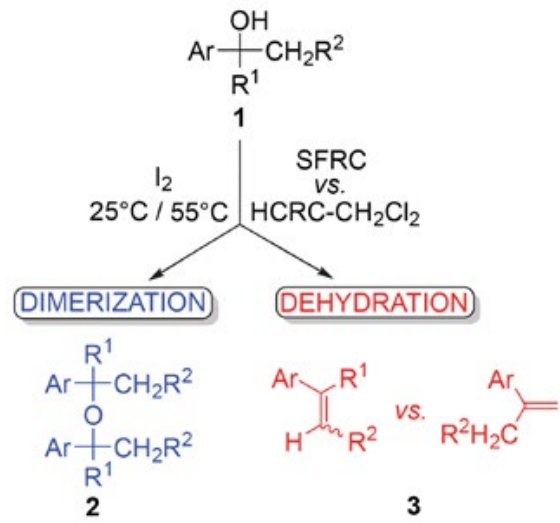

\begin{tabular}{|c|c|c|c|c|c|c|c|c|c|}
\hline \multirow[t]{2}{*}{ Entry } & \multicolumn{4}{|c|}{ Alcohol } & \multirow{2}{*}{$\begin{array}{l}\text { Reaction conditions }{ }^{\mathrm{a}} \\
\text { and time }\end{array}$} & \multirow{2}{*}{$\begin{array}{c}\text { Conversion }^{\mathrm{b}} \\
{[\%]}\end{array}$} & \multirow{2}{*}{$\begin{array}{c}\text { Dimerization } \\
2\end{array}$} & \multirow{2}{*}{ l } & \multirow{2}{*}{$\begin{array}{c}\text { Dehydration } \\
3\end{array}$} \\
\hline & Ar & $\mathbf{R}^{1}$ & $\mathbf{R}^{2}$ & 1 & & & & & \\
\hline 1 & $\mathrm{Ph}$ & $\mathrm{H}$ & $\mathrm{H}$ & $\mathbf{a}$ & A, $165 \mathrm{~h}$ & 38 & 100 & & \\
\hline 2 & & & & & $\mathrm{~B}, 165 \mathrm{~h}$ & 90 & 100 & & \\
\hline 3 & $\mathrm{Ph}$ & $\mathrm{H}$ & $\mathrm{Ph}$ & b & A, $67 \mathrm{~h}$ & 88 & 81 & & 19 \\
\hline 4 & & & & & $\mathrm{~B}, 67 \mathrm{~h}$ & 10 & 100 & & \\
\hline 5 & $\mathrm{Ph}$ & $\mathrm{CH}_{3}$ & $\mathrm{Ph}$ & c & $\mathrm{A}, 20 \mathrm{~h}$ & 100 & & & $100^{c}$ \\
\hline 6 & & & & & $\mathrm{~B}, 48 \mathrm{~h}$ & 100 & & & $100^{\mathrm{d}}$ \\
\hline 7 & $\mathrm{Ph}$ & $\mathrm{Ph}$ & $\mathrm{H}$ & d & $\mathrm{A}, 10 \mathrm{~min}$ & 100 & & & 100 \\
\hline 8 & & & & & $\mathrm{~B}, 1 \mathrm{~h}$ & 97 & & & 100 \\
\hline 9 & $\mathrm{Ph}$ & $\mathrm{Ph}$ & $\mathrm{CH}_{3}$ & e & $\mathrm{A}, 3 \mathrm{~h}^{\mathrm{e}}$ & 100 & & & 100 \\
\hline 10 & & & & & $\mathrm{~B}, 1 \mathrm{~h}$ & 10 & & & 100 \\
\hline 11 & $\mathrm{Ph}$ & $\mathrm{Ph}$ & $\mathrm{Br}$ & f & $A, 96 h^{e}$ & 98 & & & 100 \\
\hline 12 & & & & & $\mathrm{~B}, 1 \mathrm{~h}$ & 0 & & & \\
\hline 13 & $\mathrm{Ph}$ & $\mathrm{Ph}$ & $\mathrm{F}$ & g & $\mathrm{A}, 192 \mathrm{~h}^{\mathrm{e}}$ & 57 & & & 100 \\
\hline 14 & & & & & $\mathrm{~B}, 1 \mathrm{~h}$ & 0 & & & \\
\hline 15 & $p$-An & $\mathrm{H}$ & $\mathrm{H}$ & $\mathbf{h}$ & A, 15 min & 92 & 100 & & \\
\hline 16 & & & & & $\mathrm{~B}, 15 \mathrm{~min}$ & 92 & 100 & & \\
\hline 17 & $p$-An & $\mathrm{H}$ & $\mathrm{Ph}$ & $\mathbf{i}$ & A, $230 \mathrm{~min}$ & 100 & 73 & & 27 \\
\hline 18 & & & & & $\mathrm{~B}, 1 \mathrm{~h}$ & 95 & 100 & & \\
\hline 19 & $p$-An & $\mathrm{Ph}$ & $\mathrm{H}$ & $\mathbf{j}$ & $\mathrm{A}, 5 \mathrm{~min}$ & 100 & & & 100 \\
\hline 20 & & & & & $\mathrm{~B}, 5 \mathrm{~min}$ & 100 & & & 100 \\
\hline 21 & $o$-An & $\mathrm{Ph}$ & $\mathrm{H}$ & $\mathbf{k}$ & $\mathrm{A}, 15 \mathrm{~min}$ & 100 & & & 100 \\
\hline 22 & & & & & $\mathrm{~B}, 15 \mathrm{~min}$ & 100 & & & 100 \\
\hline 23 & $p$-An & $p$-An & $\mathrm{Ph}$ & 1 & A, $200 \mathrm{~min}$ & 31 & & & 100 \\
\hline 24 & & & & & $\mathrm{~B}, 200 \mathrm{~min}$ & 100 & & & 100 \\
\hline
\end{tabular}

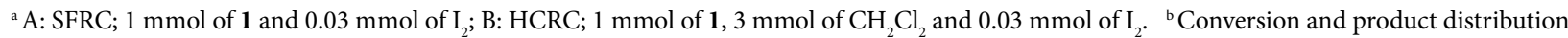
determined by ${ }^{1} \mathrm{H}$ NMR spectroscopy. ${ }^{\mathrm{c}} 4 \%$ of $(Z)$-isomer relatively to $(E)$-alkene, traces of the Hofmann alkene. ${ }^{\mathrm{d}} 5 \%$ of $(Z)$-isomer relatively to $(E)$-alkene, Zaitsev $v s$. Hofmann $=85 / 15$. $1 \mathrm{c}$ remained intact without iodine under conditions A and B. ${ }^{\mathrm{e}}$ Reaction temperature was $55^{\circ} \mathrm{C}$, in all other cases was $25^{\circ} \mathrm{C}$. 
reaction medium, that contained only 3 mol of solvent per mol of the reactant. Variously substituted secondary and tertiary benzylic alcohols $\mathbf{1 a}-\mathbf{l}$, possessing different structural features were selected as substrates (Scheme 1). Groups $\mathrm{Ar}, \mathrm{R}^{1}$, and $\mathrm{R}^{2}$ having electron-releasing substituents should enhance the stability of electron-deficient intermediates, whereas $\beta$-halogen atom $\mathrm{R}^{2}$ in $\mathbf{1 f}$ and $\mathbf{1 g}$ should increase the acidity of the methylene protons. The results of the iodine catalyzed transformation under SFRC and HCRC with alcohols 1a-1 are summarized in Table 1 indicating that tertiary alcohols underwent dehydration, while secondary alcohols predominantly dimerized into ether derivatives $\mathbf{2}$. The aggregate state of alcohols played an important role; reaction mixtures in the case of solid alcohols 1 became pasty, which proved to be essential for the reaction progress. On the other hand, liquid alcohols were less challenging in terms of their aggregate state. 1-Phenylethanol 1a yielded exclusively ether 2a under both types of the reaction conditions (entries 1 and 2, $\mathrm{A}=\mathrm{SFRC}, \mathrm{B}=\mathrm{HCRC}-\mathrm{CH}_{2} \mathrm{Cl}_{2}$ ). Introduction of an additional phenyl group at $\mathrm{C}-2(\mathbf{1 b})$ increased the reactivity affording dimer $\mathbf{2} \mathbf{b}$ as the major product (81\%), and trans-stilbene $(19 \%)$ as the sole dehydration product (entry 3$)$. Enhanced reactivity of $\mathbf{1 b}$ could be ascribed to the stabilizing effect of the additional phenyl group. A remarkable decrease in reactivity was observed for fluoro-substituted analogues of 1a: 1-(2,3,4,5,6-pentafluorophenyl)ethanol and 1-phenyl-2,2,2-trifluoroethanol remained intact after three days at $85^{\circ} \mathrm{C}$ under SFRC.

Tertiary alcohols $\mathbf{1 c}$, $\mathbf{1 d}$ and $\mathbf{1 e}$ only underwent dehydration into alkene 3 (Table 1, entries 5-10). A mixture of $(Z)$ - and (E)-1,2-diphenylpropene was formed from 1c, with the latter being the major product. The transformation of $1 \mathbf{c}$ was accompanied by the formation of 2,3-diphenyl-1-propene (entries 5 and 6). 1c remained intact without iodine under conditions $\mathrm{A}$ and $\mathrm{B}$, signifying the role of iodine. The role of acidity of the hydroxyl group and the C-2 hydrogen atom of C-2 halogenated tertiary alcohols $\mathbf{~ i f}$ and $\mathbf{1 g}$ in $\mathrm{I}_{2}$-catalyzed transformation was examined (Table 1, entries 11-14).

Reactivity was diminished in both cases, but fluoro derivative $\mathbf{1 g}$ (entry 13) reacted considerably more sluggishly than the bromo analogue 1 ff (entry 11), suggesting the ease of the proton removal from C-2 not being the most crucial in the process of dehydration, but the electron-accepting properties of the halomethyl group on the stability of the electron-deficient reaction intermediates. The introduction of methoxy group to the aromatic ring did not alter the reaction pathway in the case of 1-(4-methoxyphenyl)ethanol $\mathbf{l h}$, but dimerization was remarkably faster than with 1-phenylethanol 1a (entries 15 and 16). A similar enhancement of reactivity, induced by methoxy group, was observed also in the case of 1-(4-methoxyphenyl)-2-phenylethanol 1i; dimerization was the major process, the proportion of the dehydration grew to $27 \%$ (Table 1, entry 17) when compared with $\mathbf{1 b}$ (entry 3 ) under SFRC. Interestingly, $\mathbf{l i}$ gave dimeric ether $\mathbf{2} \mathbf{i}$ as the sole product under HCRC (entry 18). Tertiary alcohols $\mathbf{1 j}$ and $\mathbf{1 k}$ underwent dehydration, while position of the methoxy group ( $p-\mathrm{MeO}$ vs. $o-\mathrm{MeO}$ ) did not play a substantial role on the type of transformation and reaction rate (entries 19-22). The substantially lower reactivity of triaryl-substituted alcohol 11 could be ascribed to the fact that substrate has the highest melting point and the lowest solubility

Table 2. The effects of geometry, ring size and substituents on the iodine-catalyzed dehydration of tertiary alcohols 4

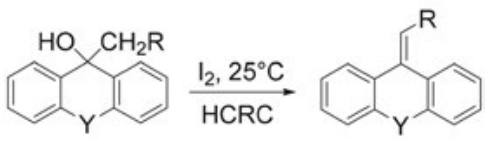

4 5

\begin{tabular}{|c|c|c|c|c|c|}
\hline \multirow{2}{*}{ Entry } & \multicolumn{2}{|c|}{ Alcohol } & \multirow{2}{*}{4} & \multirow{2}{*}{ Reaction time $^{\mathrm{a}}$} & \multirow{2}{*}{ Conversion $[\%]^{\mathrm{b}}$} \\
\hline & $\mathbf{Y}$ & $\mathbf{R}$ & & & \\
\hline 1 & l & $\mathrm{CH}_{3}$ & $\mathbf{a}$ & $15 \mathrm{~min}$ & 3 \\
\hline 2 & & & & $23 \mathrm{~h}$ & 100 \\
\hline 3 & l & $\mathrm{Ph}$ & b & $15 \mathrm{~min}$ & 0 \\
\hline 4 & & & & $96 \mathrm{~h}$ & 0 \\
\hline 5 & $\mathrm{CH}_{2} \mathrm{CH}_{2}$ & $\mathrm{CH}_{3}$ & c & $15 \mathrm{~min}$ & 79 \\
\hline 6 & & & & $154 \mathrm{~min}$ & 100 \\
\hline 7 & $\mathrm{CH}_{2} \mathrm{CH}_{2}$ & $\mathrm{Ph}$ & d & $15 \mathrm{~min}$ & 35 \\
\hline 8 & & & & $154 \mathrm{~min}$ & 100 \\
\hline 9 & $\mathrm{O}$ & $\mathrm{CH}_{3}$ & e & $15 \mathrm{~min}$ & 67 \\
\hline 10 & & & & $60 \mathrm{~min}$ & 100 \\
\hline 11 & $\mathrm{O}$ & $\mathrm{Ph}$ & f & $15 \mathrm{~min}$ & 65 \\
\hline 12 & & & & $30 \mathrm{~min}$ & 100 \\
\hline
\end{tabular}

a Reaction conditions: $1 \mathrm{mmol}$ of $4,3 \mathrm{mmol}$ of $\mathrm{CH}_{2} \mathrm{Cl}_{2}$ and $0.03 \mathrm{mmol}$ of $\mathrm{I}_{2}$ stirred at $25^{\circ} \mathrm{C} .{ }^{\mathrm{b}}$ Determined by ${ }^{1} \mathrm{H}$ NMR spectroscopy. 
among alcohols $\mathbf{1}$, and the reaction mixture required a longer time to become pasty under SFRC ( $31 \%$ conversion, entry 23). In spite of the poor solubility of 11 in $\mathrm{CH}_{2} \mathrm{Cl}_{2}$, enhanced molecular migration was achieved, reflecting in a considerably higher degree of conversion under HCRC (entry 24). In general, the reactivity of the secondary and the tertiary alcohols differs drastically regardless on the conditions SFRC or HCRC. The secondary alcohols have a strong tendency of dimerization into ethers, while the tertiary alcohols underwent dehydration into alkenes. Such a clear-cut might be surprising; however, it could be somehow anticipated. ${ }^{31}$ One of the reasons for smooth dehydration of the tertiary-, in comparison with the secondary alcohols, might be the formation of the thermodynamically more stable alkenes. In addition, dimerization of the sterically hindered tertiary alcohols is disfavored. It could be concluded that substantially higher reactivity of methoxy-substituted alcohols (Table 1, entries 15-24) is likely a consequence of stabilization of the intermediates involved - the electron deficient species. Furthermore, we examined the role of geometry, ring size and heteroatom on $\mathrm{I}_{2}$-catalyzed transformation of the dibenzo-substituted tertiary alcohols 4 under $\mathrm{HCRC}-\mathrm{CH}_{2} \mathrm{Cl}_{2}$; the results are collected in Table 2.

Fluorene derivative $4 \mathbf{a}$ yielded 9-ethylidenefluorene 5a (Table 2, entries 1 and 2) but phenyl-substituted derivative $\mathbf{4 b}$ was not reactive under these conditions (entries 3 and 4 ). The low reactivity of $\mathbf{4 a}$ and $\mathbf{4 b}$ might be associated with the geometry and formation of the potential anti-aromatic fluorenyl carbocation. ${ }^{31,63,64}$ Dibenzosuberan deriva- tives $\mathbf{4 c}$ and $\mathbf{4 d}$ are not planar and were considerably more reactive than $\mathbf{4 a}$ an additional phenyl group did not enhance the reactivity of $4 \mathbf{d}$. The substitution of a $\mathrm{CH}_{2} \mathrm{CH}_{2}$ group in the dibenzosuberan derivative with an $\mathrm{O}$-atom decreased the reactivity of 9-ethyl-xanthen-9-ol 4e, while phenyl derivative $\mathbf{4 f}$ was more reactive than $\mathbf{4 e}$. The results showed the importance of the geometry of the structure of the electron-deficient intermediates in dehydration reactions under HCRC.

Further, we examined the role of nucleophilic, protic solvents (possessing different acidity, ionizing power, hydrophobicity, and solubility of $\mathbf{1}$ and $\mathrm{I}_{2}$ ) on iodine-catalyzed transformations of secondary benzylic alcohols under HCRC (Table 3).

Three reaction pathways were operative: dimerization, dehydration and substitution. The important role of solvent added on the type of transformation was demonstrated on 1,2-diphenylethanol $\mathbf{1 b}$ (entries 1-4). No reaction took place in $\mathrm{MeOH}$, in the presence of $\mathrm{HCOOH}$, only substitution occurred yielding $\mathbf{7 b a}$ (entry 3 ); in contrast, in the presence of $\mathrm{H}_{2} \mathrm{O}$, dimerization was the dominant process (entry 4 ). Substrate $\mathbf{1 b}$ is considerably hydrophobic and does not possess a strong electron-donating group, which is reflected in its relatively low reactivity. Introduction of methoxy group to the para position of the phenyl ring remarkably enhanced the reactivity and selectivity of reaction of 1-(4-methoxyphenyl)-2-phenylethanol $\mathbf{l i}$ under HCRC (entries 5-8); contrary to $\mathbf{1 b}$, in the case of $\mathrm{MeOH}$, the methyl ether 6ia was obtained. Another surprising difference was established in the presence of

Table 3. The effect of hydroxy-substituted solvent on the iodine-catalyzed transformations of alcohols $\mathbf{1}$ under HCRC
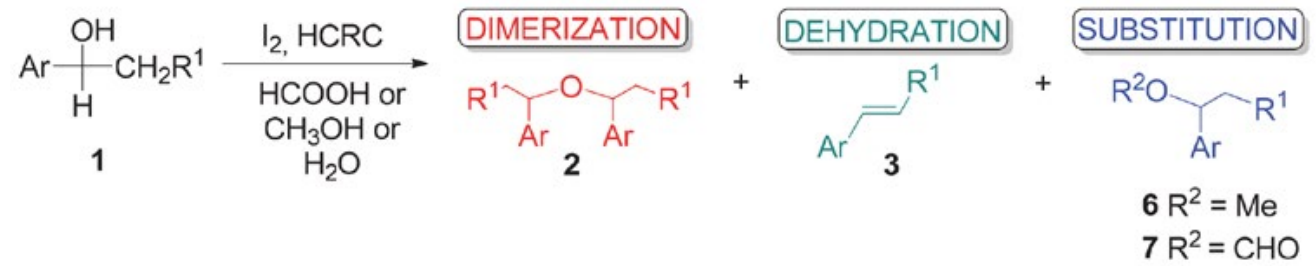

\begin{tabular}{|c|c|c|c|c|c|c|c|c|}
\hline \multirow[t]{2}{*}{ Entry } & \multicolumn{3}{|c|}{ Alcohol } & \multirow{2}{*}{$\begin{array}{l}\text { Reaction } \\
\text { conditions }^{a}\end{array}$} & \multirow{2}{*}{$\begin{array}{c}\text { Conversion } \\
{[\%]^{\mathrm{b}}}\end{array}$} & \multicolumn{3}{|c|}{ Product distribution $^{c}$} \\
\hline & Ar & $\mathbf{R}^{1}$ & 1 & & & 2 & 3 & $6 / 7$ \\
\hline 1 & $\mathrm{Ph}$ & $\mathrm{Ph}$ & b & $\mathrm{CH}_{2} \mathrm{Cl}_{2} / 67 \mathrm{~h}$ & 10 & 100 & & \\
\hline 2 & & & & $\mathrm{MeOH}^{2} / 67 \mathrm{~h}$ & 0 & & & \\
\hline 3 & & & & $\mathrm{HCOOH} / 23 \mathrm{~h}$ & 89 & & & 100 \\
\hline 4 & & & & $\mathrm{H}_{2} \mathrm{O} / 67 \mathrm{~h}$ & 14 & 90 & 10 & \\
\hline 5 & $p-A n$ & $\mathrm{Ph}$ & $\mathbf{i}$ & $\mathrm{CH}_{2} \mathrm{Cl}_{2} / 60 \mathrm{~min}$ & 97 & 100 & & \\
\hline 6 & & & & $\mathrm{MeOH} / 20 \mathrm{~h}$ & 100 & & 5 & 95 \\
\hline 7 & & & & $\mathrm{HCOOH} / 30 \mathrm{~min}$ & 100 & 87 & & $13^{\mathrm{d}}$ \\
\hline 8 & & & & $\mathrm{H}_{2} \mathrm{O} / 230 \mathrm{~min}$ & 100 & 88 & 12 & \\
\hline 9 & $p-A n$ & $\mathrm{H}$ & $\mathbf{h}$ & $\mathrm{CH}_{2} \mathrm{Cl}_{2} / 15 \mathrm{~min}$ & 92 & 100 & & \\
\hline 10 & & & & $\mathrm{MeOH} / 180 \mathrm{~min}$ & 95 & 5 & & 95 \\
\hline 11 & & & & $\mathrm{HCOOH} / 30 \mathrm{~min}$ & 98 & 8 & & 92 \\
\hline 12 & & & & $\mathrm{H}_{2} \mathrm{O} / 15 \mathrm{~min}$ & 96 & 100 & & \\
\hline
\end{tabular}

${ }^{\mathrm{a}} 1 \mathrm{mmol}$ of $1,3 \mathrm{mmol}$ of solvent and $0.03 \mathrm{mmol}$ of $\mathrm{I}_{2}$ stirred at $25{ }^{\circ} \mathrm{C}$. ${ }^{\mathrm{b}}$ Conversion and product distribution determined by ${ }^{1} \mathrm{H}$ NMR spectroscopy.

${ }^{\mathrm{c}}$ Dimerization $v s$. Dehydration $v$ s. Substitution. ${ }^{\mathrm{d}} \mathrm{A}$ ratio $2 / 7$ without $\mathrm{I}_{2}$ was $23 / 77$. 
$\mathrm{HCOOH}$, where dimerization was the main process (entry 7 ), while transformation without $\mathrm{I}_{2}$ furnished a mixture of $2 \mathbf{i}$ and $7 \mathbf{i a}$ in reversed ratio (23/77). The contrasting result suggests that iodine activated $\mathbf{1 i}$. Results of reactivity of $\mathbf{1 i}$ (entries 5-8) suggest that iodine activated 1i which dimerized predominantly in the absence of good nucleophiles (entries 5, 7 and 8). In the presence of $\mathrm{MeOH}$, a methoxy ether 6ia was the major product (entry 6), while a small extent of dehydration was observed in the cases of 1,2-diaryl-substituted alcohols only. 1-(4-methoxyphenyl) ethanol $\mathbf{l h}$, the least hydrophobic and sterically-hindered in this series, was the most reactive (entries 9-12), but with altered selectivity. In the presence of $\mathrm{CH}_{2} \mathrm{Cl}_{2}$ and $\mathrm{H}_{2} \mathrm{O}$, dimerization took place (entries 9 and 12), while substitution was the main process in the presence of $\mathrm{MeOH}$ and $\mathrm{HCOOH}$, giving 6 ha and 7 ha, respectively (entries 10 and 11). 1h was esterified with $\mathrm{HCOOH}$ under SFRC without iodine, ${ }^{32}$ thus signifying the role of $p \mathrm{~K}_{\mathrm{a}}$, and iodine has little influence on reaction of $\mathbf{1 h}$ with $\mathrm{HCOOH}$ (entry 11 ). The reactivity pattern of $\mathbf{l h}$ is similar to $\mathbf{l i}$, where substitution predominantly took place in the presence of relatively good nucleophiles, whereas dimerization is prevalent in their absence.

The alcohols and alkenes substituted with electron rich-aromatic groups might be sensitive to polymerization and are known to undergo different types of transformation. Indeed, 4-methoxybenzyl alcohol $1 \mathrm{~m}$ proved to be the right target in this regard (Table 4); under SFRC, dimerization giving $\mathbf{2} \mathbf{m}$ was the main process (entry 1 ), ipso-substitution also took place, however polymerization completely prevailed after 200 minutes producing tar material only. Similar product distribution was obtained under $\mathrm{HCRC}-\mathrm{CH}_{2} \mathrm{Cl}_{2}$ (entry 2). No other alkylation of the aromatic ring was noted.
The third reaction channel was substitution; it occurred in the presence of $\mathrm{MeOH}$ giving $6 \mathbf{m a}$, and a small proportion of dimer $\mathbf{2} \mathbf{m}$ was also formed, but no polymerization was noted, even after 190 hours (entry 3). Dimerization was the main process in the absence of a nucleophile, and ipso-substitution appeared as minor, but additional reaction channel. Considering that ipso-substitution is often related with cationic intermediates ${ }^{65}$ it could be assumed that formation of $\mathbf{8}$ is another suggestion of involvement of electron-deficient intermediates.

Next, we studied the transformation of sterically hindered and hydrophobic tertiary alcohol with the electron-rich aromatic ring, 1-phenyl-2-(4-methoxyphenyl)2 -propanol $\mathbf{~ n}$ in the presence of a catalytic amount of iodine (Table 5).

In is a substrate of choice because it possesses an activated aromatic ring for good reactivity and it could form a well stable potential intermediate to study its fate under SFRC and HCRC. Reaction mixture after 30 minutes at room temperature under SFRC contained at least three products. The major product was easily identified as the Zaitsev-type product, (E)-2-(4-methoxyphenyl)-1-phenyl-1-propene 3na (entry 1). However, the two other products had very similar physicochemical properties, reflecting in almost identical retention factors; the molecular mass of 448 indicated that dimerization occurred. The structures of these two alkenes were elucidated on the basis of 1D and 2D NMR spectra and identified as $(E)-1,5-$ diphenyl-4-methyl-2,4-bis(4-methoxyphenyl)pent-1-ene 9a and its $(Z)$-isomer $\mathbf{9 b}$. The explanation of the formation of these two alkenes is presented in Table 5. The results suggest that iodine likely induced the formation of tertiary electron-deficient intermediate or related species, probably similar to the intermediate $\mathbf{A}$; its subsequent dehydra-

Table 4. The effect of the reaction conditions on the iodine-catalyzed transformation of 4-methoxybenzyl alcohol

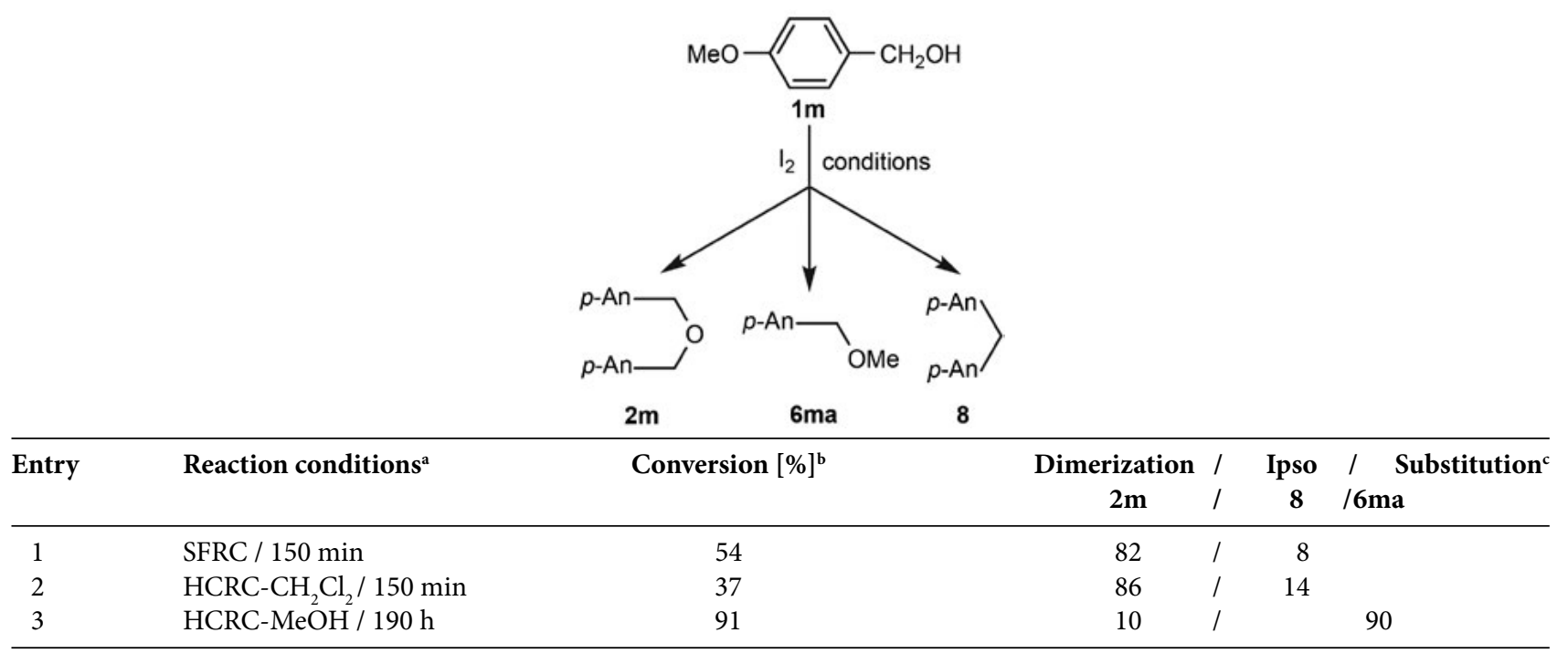

${ }^{\mathrm{a}}$ SFRC: $1 \mathrm{mmol}$ of $\mathbf{1 m}$ and $0.03 \mathrm{mmol}$ of $\mathrm{I}_{2}$, HCRC: $1 \mathrm{mmol}$ of $\mathbf{1 m}, 3 \mathrm{mmol}$ of solvent and $0.03 \mathrm{mmol}$ of $\mathrm{I}_{2}$ stirred at $25^{\circ} \mathrm{C}$. ${ }^{\mathrm{b}}$ Conversion and product distribution determined by ${ }^{1} \mathrm{H}$ NMR spectroscopy. ${ }^{\mathrm{c}}$ Dimerization $v$ s. Ipso substitution $v$ s. Substitution. 
Table 5. The effect of the reaction conditions on the iodine-catalyzed transformations of $\mathbf{l n}$

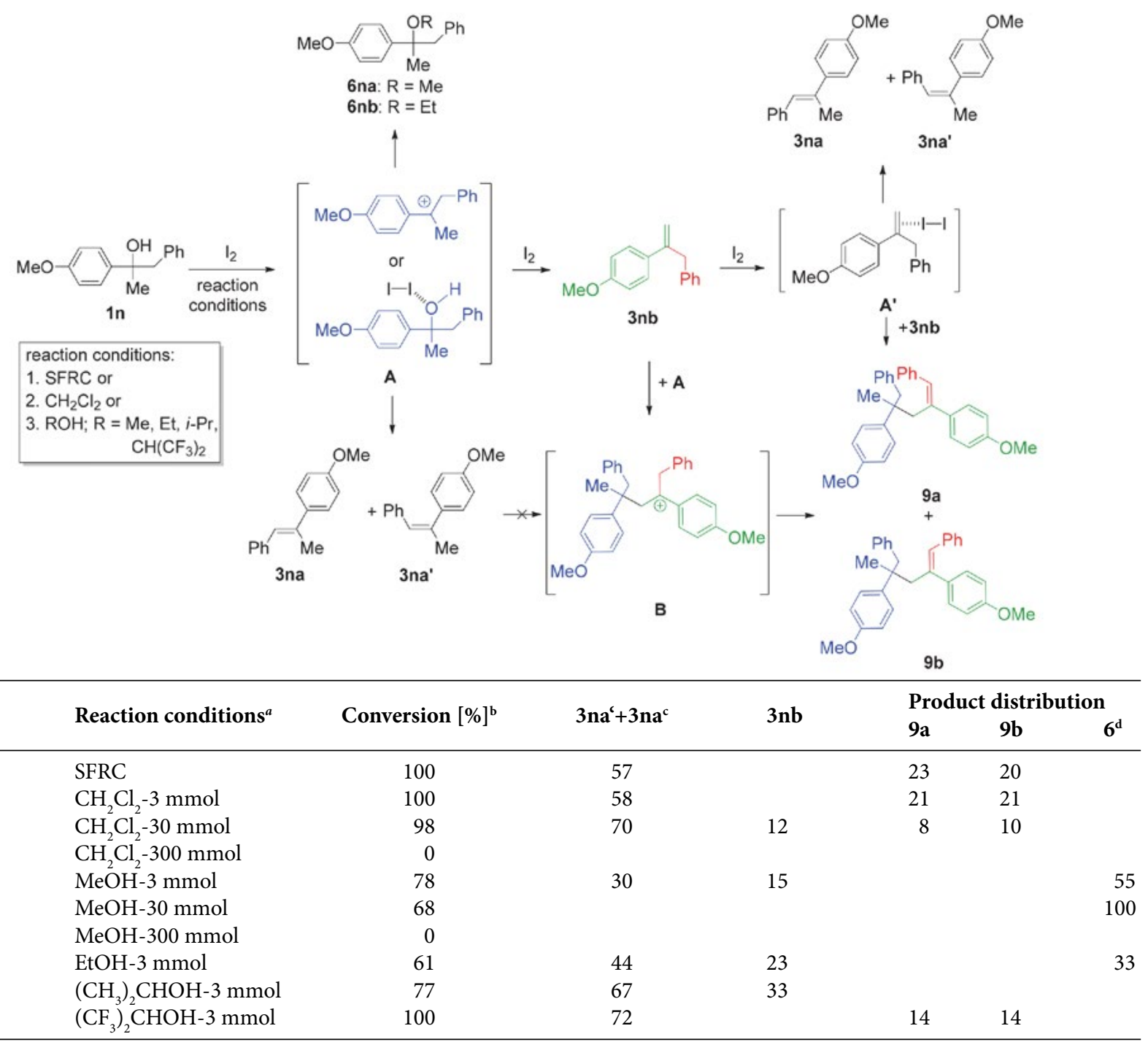

a SFRC; $1 \mathrm{mmol}$ of $1 \mathrm{n}$ and $0.03 \mathrm{mmol}$ of $\mathrm{I}_{2}, \mathrm{HCRC} ; 1 \mathrm{mmol}$ of $1 \mathrm{n}, 3,30$ or $300 \mathrm{mmol}$ of solvent and $0.03 \mathrm{mmol}$ of $\mathrm{I}_{2}$ stirred at $25^{\circ} \mathrm{C}$ for $30 \mathrm{~min}$.

${ }^{\mathrm{b}}$ Conversion determined by ${ }^{1} \mathrm{H}$ NMR spectroscopy. ${ }^{\mathrm{c}}$ Data refer to the sum of 3 na and 3na', with $(E) /(Z)=95 / 5($ entries $1,5,8-10)$ and $(E) /(Z)=$

90/10 in entries 2 and 3. ${ }^{\mathrm{d}}$ Methoxy ether $\mathbf{6} \mathbf{n a}$ in the case of $\mathrm{MeOH}$ and ethoxy ether $\mathbf{6 n b}$ in the case of EtOH were formed.

tion predominantly led to the mixture of $(Z)$ - and $(E)-2$ (4-methoxyphenyl)-1-phenyl-1-propene 3na and 3na', the Hofmann type dehydration furnished 2-(4-methoxyphenyl)-3-phenyl-1-propene 3nb. However, the latter 3nb was not stable under the studied conditions and further attacked primarily formed species $\mathbf{A}$, resulting in a cationic-like intermediate $\mathbf{B}$ or a related species, and removal of the benzylic proton furnished the isomeric alkenes 9a and $9 \mathbf{b}$. Continuing, we examined the effect of $3 \mathrm{mmol}$ of $\mathrm{CH}_{2} \mathrm{Cl}_{2}$ on the transformation of $1 \mathrm{mmol}$ of $\mathbf{1 n}$. The added solvent had no significant impact on the type of transformation (entry 2). Alkene 3nb was isolated and treated in an independent experiment with $3 \mathrm{~mol} \%$ of $\mathrm{I}_{2}$ in dichloromethane until the full consumption of $\mathbf{3 n b}$. Alkenes 3na, 3na', 9a and 9b were formed in this process potentially via $\mathbf{A}^{\prime}$. A could furnish $\mathbf{3}$ na and $\mathbf{3 n a}$ ' or it could add to the rest of $3 \mathbf{n b}$ producing $9 \mathbf{a}$ and $\mathbf{9 b}$. In contrast, an independent transformation of a mixture of the isolated alkenes 3na and 3na' with $3 \mathrm{~mol} \%$ of $\mathrm{I}_{2}$ failed, since 3na and 3na' remained intact. Alkenes 3 na and 3 na' are thermodynamically more stable than $\mathbf{3 n b}$ and were not be activated by iodine. In contrast, a larger amount $(30 \mathrm{mmol})$ of $\mathrm{CH}_{2} \mathrm{Cl}_{2}$ suppressed addition of the species $\mathbf{A}$ to alkene $\mathbf{3 n b}$ and favored the formation of the Zaitsev type product 3na (entry 3). Interestingly, $\mathbf{1 n}$ remained unreacted in a highly diluted solution of $300 \mathrm{mmol}$ of dichloromethane (entry 4). It is obvious that the vicinity of the reacting species is of the prime importance, demonstrating a crucial role of the concentration. In the presence of $3 \mathrm{mmol}$ of $\mathrm{MeOH}$, dehydration and substitution processes were observed, giving alkenes 3na, 3na' and 3nb and methoxy ether 6na (entry 5). Methanol blocked the addition of $\mathbf{A}$ to alkene $\mathbf{3 n b}$, the 
selectivity Zaitsev vs. Hofmann decreased (entry 5) in comparison with the entries 1-3. Turnover in transformation occurred in the presence of a 10-fold higher amount of $\mathrm{MeOH}$, and only ether $\mathbf{6 n a}$ was obtained (entry 6); no reaction took place in the presence of $300 \mathrm{mmol}$ of methanol (entry 7). In the presence of $3 \mathrm{mmol}$ of ethanol (entry 8 ), the same reaction pathways were observed as in the presence of methanol (entry 5). In the presence of $i-\mathrm{PrOH}$ and $\left(\mathrm{CF}_{3}\right)_{2} \mathrm{CHOH}$ (HFIP), no substitution occurred (entries 9 and 10); the Zaitsev alkene was more favored than in $\mathrm{EtOH}$ (entry 8), and finally reached $72 \%$ in the presence of HFIP, where alkene $\mathbf{3 n b}$ was further transformed to $\mathbf{9 a}$ and $\mathbf{9 b}$ (entry 10). It could be concluded that dehydration and further reaction of the formed intermediates took place under SFRC and HCRC in the presence of a non-nucleophilic solvent $\left(\mathrm{CH}_{2} \mathrm{Cl}_{2}\right)$ and HFIP. The latter solvent is known to stabilize the carbocationic intermediates ${ }^{66,67}$ and this could be an indication that our intermediates may be similar. The competition between dehydration and substitution took place under HCRC ( $3 \mathrm{mmol}$ of alcohol, entries 5 and 8$)$ in a nucleophilic solvent $(\mathrm{MeOH}$ and $\mathrm{EtOH})$, while in the presence of $30 \mathrm{mmol}$ of methanol, substitution took place exclusively. It is noteworthy to say that certain processes take place under SFRC and HCRC, but not under classical diluted conditions in a solution - the formation of $9 \mathbf{a}$ and $\mathbf{9 b}$ is such an example.

4-methoxybenzyl alcohol $1 \mathbf{m}$ proved to be very reactive substrate under the studied conditions, and it tended to yield insoluble, probably polymerized products after prolonged reaction time. Consequently, we decided to explore the reactivity of exceedingly acid sensitive $9 \mathrm{H}$-xanthene-9-ol 10 in the presence of catalytic amount of $\mathrm{I}_{2}(\mathrm{Ta}-$ ble 6).

Alcohol 10 was found to be very reactive; the reaction under SFRC was accomplished in 15 minutes at room temperature in spite of a solid reactant and catalyst. To our surprise, disproportionation took place giving the product
$11 \mathbf{a}$ and $\mathbf{1 1 b}$ as the only products (entry 1 ). Similar observation could be made in detritylation of ethers using $I_{2}$ in methanol. ${ }^{68}$ We published a detailed iodine-catalyzed disproportionation of ethers under SFRC. ${ }^{39}$ Disproportionation took place also in the presence of dichloromethane under HCRC, and it was even faster probably due to the higher migration of the reactants (entry 2). Transformation of $\mathbf{1 0}$ under HCRC in the presence of $\mathrm{MeOH}$ yielded the related methoxy ether $11 \mathrm{c}$, a very acid sensitive compound, too (entry 3 ).

In order to obtain information about the role of geometry (cyclic 9-xanthhydrol vs. acyclic diphenyl methanol) and substituents, the transformation of diphenyl methanol and bis(4-methoxyphenyl)methanol was studied under HCRC- $\mathrm{CH}_{2} \mathrm{Cl}_{2}$. Only dimerization took place, and no disproportionation was noted. Dimerization of bis(4-methoxyphenyl)methanol to bis[bis(4-methoxyphenyl)methyl] ether occured in five minutes, while bis(diphenylmethyl) ether was obtained in $71 \%$ yield after two days at room temperature. In $\mathrm{MeOH}$, substitution took place, and bis(4-methoxyphenyl)methyl methyl ether was formed in $77 \%$ yield. Diphenyl methanol yielded the corresponding methyl ether as the main product, and a small amount of bis(diphenylmethyl)ether. Bis(pentafluorophenyl)methanol was found inert in the $\mathrm{I}_{2}$-catalyzed reaction; no conversion was noted after two days at $85{ }^{\circ} \mathrm{C}$ under SFRC. It can be concluded that reactivity is essentially dependent on the structure and geometry of the alcohol; the electron-accepting groups tend to disfavor the transformation.

4-Methoxyphenyl-substituted alcohols $\mathbf{1 m}$ and $\mathbf{1 h}$ were proved very sensitive to the reaction conditions; for that reason, we investigated the role of $p \mathrm{~K}_{\mathrm{a}}$ of alcohols added under HCRC, Table 7.

Dimerization of 4-methoxybenzyl alcohol $1 \mathrm{~m}$ was the main process in the absence of a good nucleophile ( $\mathrm{HCRC}-\mathrm{CH}_{2} \mathrm{Cl}_{2}$ ), while ipso-substitution took place as

Table 6. The effect of the reaction conditions on iodine-catalyzed transformation of $\mathbf{1 0}$

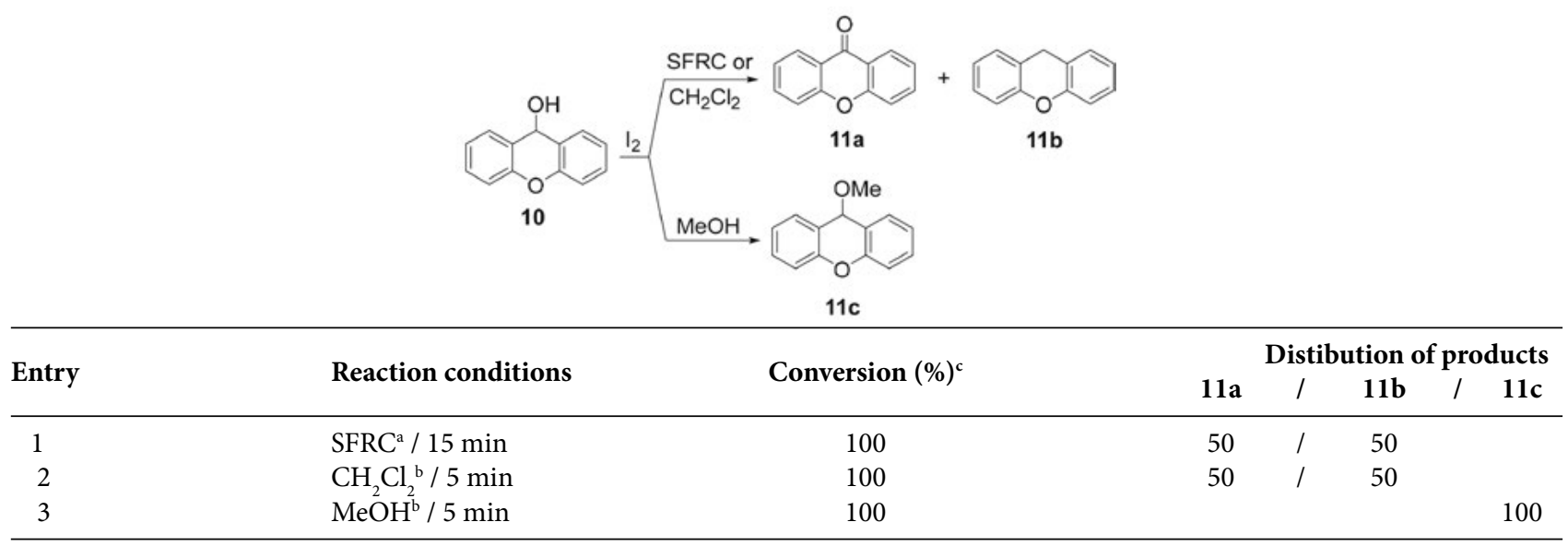

a $1 \mathrm{mmol}$ of $10,0.03 \mathrm{mmol}$ of $\mathrm{I}_{2}, \mathrm{~T}=25^{\circ} \mathrm{C} .{ }^{\mathrm{b}} 1 \mathrm{mmol}$ of $10,3 \mathrm{mmol}$ of solvent, $0.03 \mathrm{mmol} \mathrm{I}_{2}, \mathrm{~T}=25^{\circ} \mathrm{C}$. ${ }^{\mathrm{c}}$ Conversion and product distribution determined by ${ }^{1} \mathrm{H}$ NMR spectroscopy. 
Table 7. The effect of the HCRC on the transformation of $1 \mathbf{m}$ and $\mathbf{1 h}$

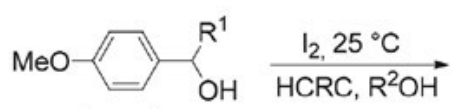

1m: $\mathrm{R}^{1}=\mathrm{H}$

1h: $R^{1}=M e$

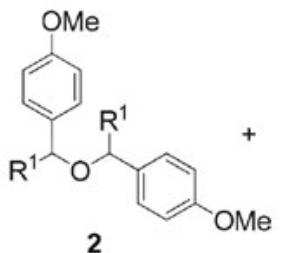

2

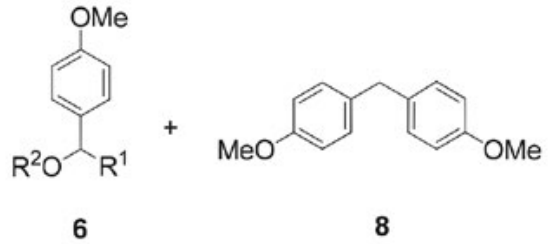

$\mathrm{R}^{2}=\mathrm{Me}, \mathrm{Et}, i-\mathrm{Pr}, \mathrm{CH}_{2} \mathrm{CF}_{3}, \mathrm{CH}\left(\mathrm{CF}_{3}\right)_{2}$

\begin{tabular}{|c|c|c|c|c|c|c|c|c|}
\hline Entry & 1 & $\mathrm{R}^{2} \mathrm{OH}$ & Reaction time $^{a}$ & Conversion $(\%)^{\mathrm{b}}$ & $\begin{array}{c}\text { Dimerization } \\
2\end{array}$ & $\begin{array}{l}1 \\
1\end{array}$ & $\begin{array}{c}\text { Substitution } \\
6\end{array}$ & $\begin{array}{cc}\text { / } & \text { Ipso } \\
/ & \mathbf{8}\end{array}$ \\
\hline 1 & $1 \mathrm{~m}$ & $\mathrm{MeOH}$ & $190 \mathrm{~h}$ & 91 & 10 & l & 90 & \\
\hline 2 & $1 \mathrm{~m}$ & $\mathrm{EtOH}$ & $360 \mathrm{~h}$ & 80 & 16 & / & 80 & 4 \\
\hline 3 & $1 \mathrm{~m}$ & $i-\mathrm{PrOH}$ & $360 \mathrm{~h}$ & 67 & 29 & l & 64 & 7 \\
\hline 4 & $1 \mathrm{~m}$ & $\mathrm{CF}_{3} \mathrm{CH}_{2} \mathrm{OH}$ & $1 \mathrm{~h}$ & 40 & 77 & l & / & 23 \\
\hline 5 & $1 \mathrm{~m}$ & $\left(\mathrm{CF}_{3}\right)_{2} \stackrel{2}{\mathrm{CHOH}}$ & $1 \mathrm{~h}$ & 30 & 65 & & 1 & 35 \\
\hline 6 & $1 \mathrm{~h}$ & $\mathrm{MeOH}$ & $15 \mathrm{~min}$ & 43 & 14 & / & 86 & \\
\hline 7 & 1h & $\mathrm{MeOH}$ & $3 \mathrm{~h}$ & 95 & 5 & l & 95 & \\
\hline 8 & 1h & $\mathrm{EtOH}$ & $15 \mathrm{~min}$ & 49 & 61 & l & 39 & \\
\hline 9 & 1h & $\mathrm{EtOH}$ & $25 \mathrm{~h}$ & 98 & 12 & l & 88 & \\
\hline 10 & $1 \mathrm{~h}$ & $i-\mathrm{PrOH}$ & $15 \min$ & 37 & 80 & l & 20 & \\
\hline 11 & $1 \mathrm{~h}$ & $i-\mathrm{PrOH}$ & $25 \mathrm{~h}$ & 98 & 25 & l & 75 & \\
\hline 12 & 1h & $\mathrm{CF}_{3} \mathrm{CH}_{2} \mathrm{OH}$ & $15 \mathrm{~min}$ & 83 & 20 & l & 80 & \\
\hline 13 & 1h & $\mathrm{CF}_{3} \mathrm{CH}_{2}^{2} \mathrm{OH}$ & $2.5 \mathrm{~h}$ & 96 & 8 & l & 92 & \\
\hline 14 & $1 \mathrm{~h}$ & $\left(\mathrm{CF}_{3}\right)_{2} \mathrm{CHOH}$ & $15 \min$ & 60 & 100 & & & \\
\hline
\end{tabular}

${ }^{\mathrm{a}} 1 \mathrm{mmol}$ of $1,3 \mathrm{mmol}$ of $\mathrm{R}^{2} \mathrm{OH}, 0.03 \mathrm{mmol}$ of $\mathrm{I}_{2}, \mathrm{~T}=25^{\circ} \mathrm{C}$. ${ }^{\mathrm{b}}$ Conversion and product distribution determined by ${ }^{1} \mathrm{H}$ NMR spectroscopy.

well (Table 4, entry 2). The addition of alcohols extensively retarded transformation of $\mathbf{1} \mathbf{m}$ (Table 7 , entries 1-3); the proportion of substitution is decreasing with the growing sterical hindrance and the reducing nucleophilicity of the solvent. A noteworthy modulation of the reactivity was noted in the case of more acidic and low nucleophilic 2,2,2-trifluoroethanol (TFE) and HFIP. Starting 1 m displayed a strong tendency of polymerization in the latter two alcohols, and after too long reaction time, the tar material was only isolated. The reaction time was consequently limited to one hour and dimerization and ipso-substitu- tion were the only processes (entries 4 and 5). Both alcohols are poor nucleophiles, and no substitution took place. An additional methyl group contributed to the substantially higher reactivity of 1-(4-methoxyphenyl)ethanol $\mathbf{l h}$ in comparison with $\mathbf{1 m}$, dimerization and substitution became the only reaction channels. Dimerization was the exclusive transformation in the absence of a good nucleophile ( $\mathrm{HCRC}-\mathrm{CH}_{2} \mathrm{Cl}_{2}$ ) (Table 3, entry 9). In the presence of $\mathrm{MeOH}, \mathrm{EtOH}$ and $i$ - $\mathrm{PrOH}$ substitution and dimerization took place (Table 7, entries 7, 9 and 11), exhibiting a similar reactivity pattern as in the case of $\mathbf{1} \mathbf{m}$. It is evident that

Table 8. The effect of the hydroxy-substituted solvent on the conversion of $\mathbf{2 h}$ under HCRC

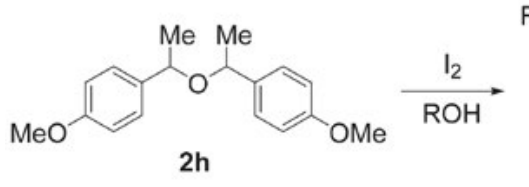

$\mathrm{R}=\mathrm{Me}, \mathrm{Et}, i-\mathrm{Pr}, \mathrm{CH}_{2} \mathrm{CF}_{3}, \mathrm{Ac}$

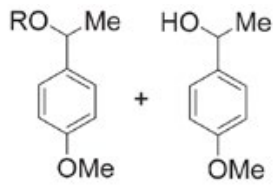

6
$1 \mathrm{~h}$

\begin{tabular}{|c|c|c|c|c|c|c|}
\hline Entry & ROH & Reaction time $^{a}$ & Conversion (\%) & 6 & l & $1 \mathrm{~h}$ \\
\hline 1 & $\mathrm{MeOH}$ & $3 \mathrm{~h}$ & 75 & 97 & l & 3 \\
\hline 2 & $\mathrm{EtOH}$ & $15 \mathrm{~h}$ & 74 & 97 & l & 3 \\
\hline 3 & $i-\mathrm{PrOH}$ & $15 \mathrm{~h}$ & 52 & 96 & l & 4 \\
\hline 4 & $\mathrm{CF}_{3} \mathrm{CH}_{2} \mathrm{OH}$ & $1.5 \mathrm{~h}$ & 91 & 95 & l & 5 \\
\hline 5 & $\mathrm{CH}_{3} \mathrm{COOH}$ & $6 \mathrm{~h}$ & 79 & $88^{c}$ & l & 12 \\
\hline
\end{tabular}

${ }^{\mathrm{a}}$ Reaction conditions: $1 \mathrm{mmol}$ of $2 \mathbf{h}, 3 \mathrm{mmol} \mathrm{ROH}, 0.03 \mathrm{mmol}$ of $\mathrm{I}, \mathrm{T}=25{ }^{\circ} \mathrm{C}$, R. t. (reaction time) ${ }^{\mathrm{b}}$ Conversion and product distribution determined by ${ }^{1} \mathrm{H}$ NMR spectroscopy. $\quad{ }^{\mathrm{c}}$ The product is 1-(4-methoxyphenyl)ethyl acetate 6 he. 
the dimeric ether $\mathbf{2}$ is a kinetically controlled product (entries 6-11), and iodine could catalyze its transetherification. ${ }^{69}$ Transformations of $\mathbf{l h}$ were faster in presence of the fluorinated solvents; in the case of a better nucleophile TFE, substitution almost completely prevailed (entries 12 and 13), while in the presence of HFIP dimerization was the only process (entry 14). It could be concluded that reactivity patterns of $\mathbf{1 m}$ and $\mathbf{l h}$ in the presence of iodine under SFRC and HCRC are similar. Dimerization of both alcohols is the key process in the absence of a good nucleophile, while substitution took place predominantly in the presence of a good nucleophile.

It is evident in the Table 7 that dimerization is followed by transetherification, and we decided to further investigate this rather unexplored process, Table 8.

Functionalization of $\mathbf{2 h}$ in the presence of methanol under HCRC yielded the corresponding methyl ether $\mathbf{6 h a}$ (97\%) and $3 \%$ of the alcohol $\mathbf{l h}$ (entry 1). This is an indication that relation between $\mathbf{l h}$ and $\mathbf{2 h}$ is reversible. The conversion roughly corresponds with the nucleophilicity of the alcohols (entries 1-3); in the case of the most sterically hindered and least nucleophilic $i$-PrOH the lowest conversion was achieved. A surprising turning point was observed in $\mathrm{CF}_{3} \mathrm{CH}_{2} \mathrm{OH}$ (entry 4). Although considerably more acidic and worse nucleophile than ethanol, the highest conversion was achieved in $\mathrm{CF}_{3} \mathrm{CH}_{2} \mathrm{OH}$. The result reflects the much stronger stabilization of the reaction intermediates in comparison with the simple alkyl alcohols. Transformation of $\mathbf{2} \mathbf{h}$ in the presence of acetic acid yielded the corresponding acetate ester $\mathbf{6 h e}$ (entry 5), demonstrating the carboxylic acids are suitable nucleophiles in this reaction. Products 6 were considerably more stable than $\mathbf{2 h}$, and remained intact in the presence of iodine.

The Hammett correlation ${ }^{70,71}$ is a convenient tool for the estimation of the nature of the reaction intermediates and the type of bond cleavage, and in the case of ionic in- termediates, the degree of the charge developed. It is determined under homogenous conditions in diluted solution; however, we decided to examine the relative reactivity of the substituted 1-phenylethanols in $\mathrm{I}_{2}$-catalyzed dimerization under SFRC (Figure 1). The SFRC conditions are challenging, and therefore the Hammett correlation has been rarely studied. ${ }^{72}$

The relative reactivity of 1-phenylethanol $\mathbf{1 a}$ toward its substituted 4-F 1o, 3-Me 1p, 3-MeO 1q, 4-Cl 1r and 4 - $\mathrm{Br} 1 \mathrm{~s}$ derivatives was studied at $55^{\circ} \mathrm{C}$, all the alcohols are liquid at given temperature. In all cases, dimeric ethers $\mathbf{2 a}$ and 2o-s were formed and good Hammett correlation $\left(r^{2}=\right.$ $0.98)$ was obtained utilizing $\sigma^{+}$substituent constants. The slope $\rho^{+}=-2.8$ suggests the transition state involving electron-deficient intermediates with a partial developed charge in a rate-determining step. A similar value of $\rho=$ -2.76 was obtained in $\mathrm{I}_{2}$-catalyzed dihydroperoxidation of benzaldehydes in acetonitrile at $22^{\circ} \mathrm{C}^{73}$ It can be summarized that iodine has a remarkable feature of generation of species that would normally require the use of a strong acid.

In order to demonstrate the role of iodine, reactivity of different catalytic systems were examined on an exceedingly acid-sensitive substrate $9 H$-xanthene-9-ol 10, giving $11 \mathbf{a}$ and $11 \mathbf{b}$ smoothly, ${ }^{74}$ Table 9.

Entries 1 and 2 were added from Table 6 for easier comparison. Transformation of $\mathbf{1 0}$ in the presence of phosphomolybdic acid hydrate under SFRC was much less effective in comparison with the $\mathrm{I}_{2}$-catalyzed reaction (entry 3 ), while reaction in the presence of methanol yielded the methoxy ether $11 \mathrm{c}$ with $84 \%$ selectivity (entry 4 ). Expectedly, disproportionation of $\mathbf{1 0}$ in the presence of $57 \%$ aqueous solution of $\mathrm{HI}$ was the only process ${ }^{75}$ (entry 5 ), whereas in the presence of methanol $80 \%$ of $11 \mathrm{c}$ was formed (entry 6); displaying similar reactivity in the presence of heteropoly acid and HI (entries 3-6). Reaction of<smiles>[R]c1ccc(C(O)c2ccccc2)c(C(C)(O)c2ccccc2)c1</smiles>

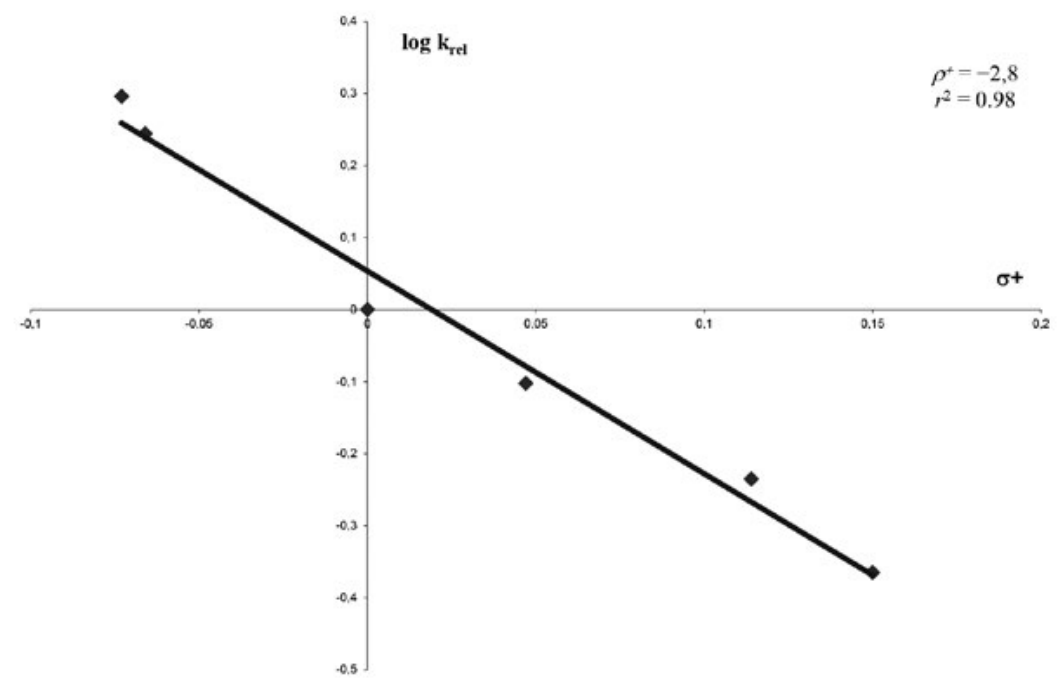

Figure 1. Hammett correlation analysis on $\mathrm{I}_{2}$-catalyzed dimerization of $\mathbf{1}$. 
Table 9. Comparison of activity of different catalysts on the transformation of $10^{\mathrm{a}}$

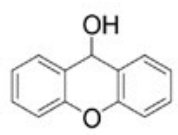

10

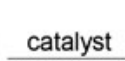
conditions

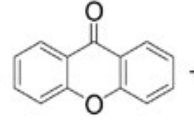

$11 \mathrm{a}$

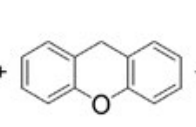

11b

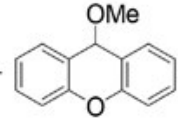

11c

\begin{tabular}{|c|c|c|c|c|c|c|}
\hline Entry & Catalyst & Reaction time, rt & Conversion $(\%)^{b}$ & $11 \mathrm{a}$ & $11 b$ & $11 \mathrm{c}$ \\
\hline 1 & $3 \% \mathrm{I}_{2} / \mathrm{SFRC}^{\mathrm{c}}$ & $15 \min$ & 100 & 50 & 50 & \\
\hline 2 & $3 \% \mathrm{I}_{2} / \mathrm{MeOH}$ & $5 \mathrm{~min}$ & 100 & & & 100 \\
\hline 3 & $\mathrm{PMA}^{2} / \mathrm{SFRC}^{\mathrm{d}}$ & $15 \mathrm{~min}$ & $29^{e}$ & 7 & 7 & \\
\hline 4 & $\mathrm{PMA} / \mathrm{MeOH}^{\mathrm{f}}$ & $5 \mathrm{~min}$ & 100 & 8 & 8 & 84 \\
\hline 5 & $3 \%$ HI $(57 \%)^{g}$ & $15 \min$ & 100 & 50 & 50 & \\
\hline 6 & $3 \% \mathrm{HI}(57 \%) / \mathrm{MeOH}^{\mathrm{h}}$ & $5 \mathrm{~min}$ & 100 & 10 & 10 & 80 \\
\hline 7 & $3 \% \mathrm{I}_{2} / 3 \% \mathrm{H}_{2} \mathrm{O} / \mathrm{MeOH}^{\mathrm{i}}$ & $5 \mathrm{~min}$ & 100 & & & 100 \\
\hline 8 & $3 \% \mathrm{I}_{2}^{2} / 3 \% \mathrm{KI} / \mathrm{SFRC}$ & $15 \mathrm{~min}$ & 100 & 50 & 50 & \\
\hline 9 & $3 \% \mathrm{I}_{2}^{2} / 3 \% \mathrm{KI} / \mathrm{MeOH}^{\mathrm{k}}$ & $5 \mathrm{~min}$ & 100 & & & 100 \\
\hline 10 & $3 \% \mathrm{I}_{2}^{2} / 3 \% \mathrm{Bu}_{4} \mathrm{NI} / \mathrm{SFRC}^{\mathrm{l}}$ & $15 \mathrm{~min}$ & $40^{\mathrm{m}}$ & 2 & 2 & \\
\hline 11 & $3 \% \mathrm{I}_{2}^{2} / 3 \% \mathrm{Bu}_{4}^{4} \mathrm{NI} / \mathrm{MeOH}^{\mathrm{n}}$ & $5 \mathrm{~min}$ & 95 & & & 100 \\
\hline
\end{tabular}

${ }^{\mathrm{a}}$ Reaction conditions: 10 (1 mmol, $\left.198 \mathrm{mg}\right)$ and various catalysts, $\mathrm{rt} .{ }^{\mathrm{b}}$ Conversion and product distribution determined by ${ }^{1} \mathrm{H}$ NMR spectroscopy. ${ }^{\mathrm{c}}$ Entries 1 and 2 from Table $6 .{ }^{\mathrm{d}} \mathbf{1 0}(1 \mathrm{mmol}, 198 \mathrm{mg})$ and phosphomolybdic acid hydrate $\left(\mathrm{PMA}_{3} \mathrm{H}_{3}\left[\mathrm{P}\left(\mathrm{Mo}_{3} \mathrm{O}_{10}\right)_{4}\right] \cdot \mathrm{xH}_{2} \mathrm{O}\right), 60 \mathrm{mg}$. ${ }^{\mathrm{e}} 71 \%$ of unreacted 10 and $15 \%$ of a new, unidentified product presumably a ROR type dimer of $\mathbf{1 0}{ }^{\mathrm{f}} \mathbf{1 0}(1 \mathrm{mmol}, 198 \mathrm{mg})$, methanol (3 mmol, $\left.96 \mathrm{mg}\right)$ and PMA (60 mg). ${ }^{\mathrm{g}} 10$ (1 mmol, $\left.198 \mathrm{mg}\right)$ and $\mathrm{HI}(57 \%$ aqueous solution, $0.03 \mathrm{mmol}, 6.7 \mathrm{mg}) .{ }^{\mathrm{h}} 10$ (1 mmol, $\left.198 \mathrm{mg}\right)$, methanol $(3 \mathrm{mmol}, 96 \mathrm{mg})$ and $\mathrm{HI}(57 \%$ aqueous solution, $0.03 \mathrm{mmol}, 6.7 \mathrm{mg}) .{ }^{\mathrm{i}} 10(1 \mathrm{mmol}, 198 \mathrm{mg}), \mathrm{H}_{2} \mathrm{O}(0.03 \mathrm{mmol}, 0.6 \mathrm{mg})$, methanol $(3 \mathrm{mmol}, 96 \mathrm{mg}) \mathrm{and} \mathrm{\textrm {I } _ { 2 }}(0.03 \mathrm{mmol}, 7.6 \mathrm{mg})$. ${ }^{j} \mathrm{KI}(0.03 \mathrm{mmol}, 5 \mathrm{mg})$ and $\mathrm{I}_{2}(0.03 \mathrm{mmol}, 7.6 \mathrm{mg})$ were stirred for 20 minutes, 10 (1 mmol, $\left.198 \mathrm{mg}\right)$ was added. ${ }^{\mathrm{k}} \mathrm{KI}(0.03 \mathrm{mmol}, 5 \mathrm{mg}), \mathrm{I}_{2}(0.03$ mmol, $7.6 \mathrm{mg})$ were stirred for 20 minutes, $10(1 \mathrm{mmol}, 198 \mathrm{mg})$ and methanol $(3 \mathrm{mmol}, 96 \mathrm{mg})$ were added. ${ }^{1} \mathrm{I}_{2}(0.03 \mathrm{mmol}, 7.6 \mathrm{mg})$ and Bu${ }_{4} \mathrm{NI}$ $(0.03 \mathrm{mmol}, 11.1 \mathrm{mg})$ were stirred for 20 minutes, $10(1 \mathrm{mmol}, 198 \mathrm{mg})$ was added. ${ }^{\mathrm{m}} 60 \%$ of unreacted 10 and $36 \%$ of a new product, presumably a ROR type dimer of $10 .{ }^{\mathrm{n}} \mathrm{I}_{2}(0.03 \mathrm{mmol}, 7.6 \mathrm{mg}), \mathrm{Bu}_{4} \mathrm{NI}(0.03 \mathrm{mmol}, 11.1 \mathrm{mg})$ were stirred for 20 minutes, 10 (1 mmol, $\left.198 \mathrm{mg}\right)$ and methanol (3 mmol, $96 \mathrm{mg}$ ) were added.

10 in a mixture of $3 \%$ of $\mathrm{I}_{2}, 3 \%$ of water and $3 \mathrm{mmol}$ of methanol furnished $11 \mathrm{c}$ as the only product (entry 7 ). The result indicates that iodine is relatively highly water tolerant ${ }^{76}$ and retains its catalytic activity in contrast to the numerous other Lewis acids. Iodine and KI were stirred together before $\mathbf{1 0}$ were added in order to establish the effect of iodine complexation. Disproportionation took place quantitatively, indicating at least two possible scenarios. Complexation of iodine and potassium iodide might be poor; on the other hand, triiodide could possibly catalyze the disproportionation (entry 8). Reaction of $\mathbf{1 0}$ with the system $\mathrm{I}_{2} / \mathrm{KI} / \mathrm{MeOH}$ yielded the methoxy ether $11 \mathrm{c}$ as a

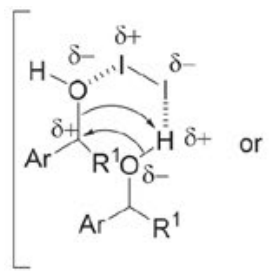

TS-1

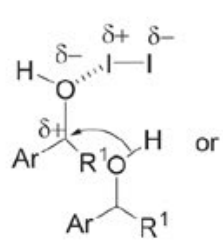

TS-2

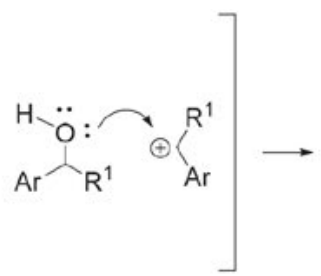

TS-3

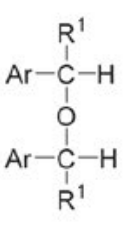

2

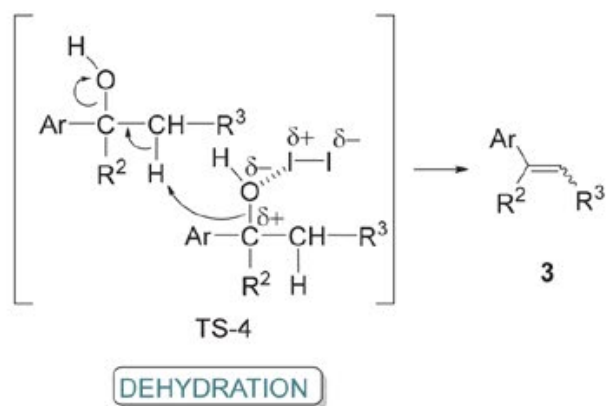

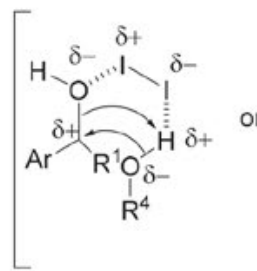

TS-5

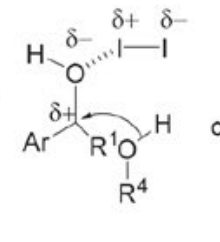

TS-6

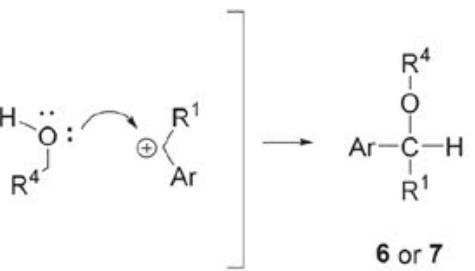

TS-7

\section{SUBSTITUTION}

Scheme 1. A suggested role of iodine in transformation of alcohols under SFRC and HCRC. 
sole product (entry 9). Additional complexation of $\mathrm{I}_{2}$ with $\mathrm{Bu}_{4} \mathrm{NI}$ almost completely suppressed disproportionation, suggesting that formation of triiodide was a key (entry 10). Reaction of 10 with $\mathrm{I}_{2} / \mathrm{Bu}_{4} \mathrm{NI}$ in the presence of methanol yielded the methoxy ether 11c only, while no disproportionation took place (entry 11). In reactions in entries 3 and 10 an unidentified product appeared, seemingly a dimeric ether of 10. There is often speculated, though not experimentally proven, that the in-situ formed $\mathrm{HI}$ is the actual catalyst in the iodine-catalyzed transformations. ${ }^{77} \mathrm{~A}$ potential formation of $\mathrm{HI}$ would probably result in a loss of the reaction selectivity (comparison of entries 2 and 6). The results indicate that iodine was the active catalyst, where complexation changed the reaction pathway considerably. Additionally, iodine was titrated with a standard solution of $\mathrm{Na}_{2} \mathrm{~S}_{2} \mathrm{O}_{3}$ after the end of the disproportionation of 10. The entire amount of iodine was present at the end of the reaction. Similar observation was made in the case of dimerization of a secondary alcohol and substitution reaction with methanol, strongly indicating iodine as the active catalyst in these reactions.

A tentative explanation of the reaction pathways is presented on Scheme 2. The driving force in all cases is presumably polarization of the reactants by iodine. We proposed such halogen bond ${ }^{78}$ activation in disproportionation of ethers under SFRC ${ }^{39}$, which is in agreement with recent computationa ${ }^{37}$ and experimental studies. ${ }^{38} \mathrm{~A}$ simultaneous TS- 1 or two separated activation processes TS-2, including carbenium ion TS- 3 could be proposed as the key steps in the dimerization process. In the absence of a better nucleophile, the starting alcohol took over a role of an attacking nucleophile, affording the dimer $\mathbf{2}$. The dehydration process of the tertiary alcohols might be initiated by polarization of the starting alcohol as shown in TS-4. The substitution step is suggested as a concomitant activation TS-5 or a divided activation TS- 6 or by carbenium ion TS-7.

In the presence of added stronger nucleophile, substitution products $\mathbf{6}$ and $\mathbf{7}$ substantially prevailed over the dimerization products 2 .

\section{Conclusions}

To summarize, we have studied iodine-catalyzed transformations of aryl-substituted alcohols under SFRC and under HCRC, the concentration was proved to have an exceptional impact on the transformation. Achieving a pasty aggregate state of solid substrates in the presence of $\mathrm{I}_{2}$ was of vital importance for the reaction progress. Primary and secondary alcohols underwent two main transformations, depending on the reaction conditions. Dimerization took place in absence of the good nucleophiles under SFRC and HCRC, while substitution prevailed in presence of the good nucleophiles. The tertiary alcohols exhibited a strong tendency of dehydration into alkenes, which is in sharp contrast with the reactivity of primary and second- ary alcohols. The difference in thermodynamic stability of the alkenes, derived from the tertiary and the secondary alcohols, is supposedly a driving force for the observed selectivity. Substitution was another process observed in the presence of the hydroxylic solvents; their acidity, nucleophilicity and hydrophobicity were important parameters for studying the reactivity of those alcohols. 4-Methoxyphenyl-substituted alcohols possessed higher reactivity than phenyl analogues; their pentafluorophenyl counterparts were unreactive under the studied conditions. The results indicated the electron-deficient intermediates to be likely involved in these processes, the geometries of the molecule and heteroatom share an important part in reactivity. 4-Methoxybenzyl alcohol yielded its dimeric ether and bis(4-methoxyphenyl)methane, a product derived via the $\mathrm{I}_{2}$-catalyzed ipso-substitution. 4-Methoxybenzyl alcohol exhibited higher reactivity in TFE and HFIP than in EtOH and in $i$-PrOH under HCRC, thus indicating stronger stabilization of the reaction intermediates in the fluorinated alcohols. A tertiary benzylic alcohol $\mathbf{1 n}$ was demonstrated to possess a special reactivity. It appears that upon its dehydration all three possible alkenes were obtained. The thermodynamically less stable alkene unexpectedly reacted with the initially formed intermediate, furnishing two dimeric alkenes. It is worth mentioning that certain processes take place under SFRC and HCRC, but not under the classical diluted conditions. This is an indication that reacting species have to be in close vicinity. Iodine catalyzed the disproportionation of $9 H$-xanthene-9-ol 10 under SFRC and HCRC, and in contrast, the substitution took place in the presence of $\mathrm{MeOH}$. Iodine is a convenient catalyst for transetherification under mild conditions, it has a potential for interconversion of ether to ester. The Hammett correlation analysis of the $\mathrm{I}_{2}$-catalyzed dimerization of substituted 1-phenylethanols under SFRC $\left(\mathrm{T}=55^{\circ} \mathrm{C}\right)$ furnished straight-line $\rho^{+}=-2.8\left(r^{2}=0.98\right)$. This fact strongly suggests the involvement of the electron-deficient intermediates with a certain degree of the developed charge in the transition state.

\section{Acknowledgement}

We thank Prof. Marko Zupan for his initiative part of the research. We are grateful the Slovenian Research Agency for the financial support (P1-0134 and P1-0230), to Dr. D. Žigon at the Mass Spectroscopy Centre at the 'Jožef Stefan' Institute in Ljubljana, and to Mrs. T. Stipanovič and Prof. J. Svete for elemental combustion analysis.

\section{References}

\footnotetext{
1. J. Clark, D. Macquarrie, Eds. Handbook of Green Chemistry \& Technology; Blackwell: Oxford, U. K. 2002.

DOI:10.1002/9780470988305
} 
2. M. Lancaster, Green Chemistry: An Introductory Text; Royal Society of Chemistry, Cambridge, U. K., 2002.

3. P. Tundo, V. Esposito, V., (Eds.): Green Chemical Reactions; Springer, Dordrecht, Netherlands, 2008.

4. K. Tanaka, (Ed.): Solvent-Free Organic Synthesis; Wiley-VCH: Weinheim, Germany, 2009.

5. P. J. Walsh, H. Li, C. A. de Parrodi, Chem. Rev. 2007, 107, 2503-2545. DOI:10.1021/cr0509556

6. M. B. Gawande, V. D. B. Bonifácio, R. Luque, P. S. Branco, R. S. Varma, ChemSusChem 2014, 7, 24-44.

DOI:10.1002/cssc.201300485

7. M. A. P. Martins, C. P. Frizzo, D. N. Moreira, L. Buriol, P. Machado, Chem. Rev. 2009, 109, 4140-4182. DOI:10.1021/cr9001098

8. S. Nakamatsu, S. Toyota, W. Jones, F. Toda, Chem. Commun. 2005, 3808-3810. DOI:10.1039/b503922c

9. A. Orita, G. Uehara, K. Miwa, J. Otera, Chem. Commun. 2006, 4729-4731. DOI:10.1039/b609567d

10. M. Feller, A. Karton, G. Leitus, J. M. L. Martin, D. Milstein, J. Am. Chem. Soc. 2006, 128, 12400-12401.

DOI:10.1021/ja0641352

11. Z. Tang, Z.-H. Yang, L.-F. Cun, L.-Z. Gong, A.-Q. Mi, Y.-Z. Jiang, Org. Lett. 2004, 6, 2285-2287;

DOI:10.1021/ol049141m

12. I. Pravst, M. Zupan, S. Stavber, Tetrahedron Lett. 2006, 47, 4707-4710. DOI:10.1016/j.tetlet.2006.04.119

13. G. Angelici, R. J. Corrêa, S. J. Garden, C. Tomasini, Tetrahedron Lett. 2009, 50, 814-817.

DOI:10.1016/j.tetlet.2008.12.007

14. Y. Hayashi, T. Sumiya, J. Takahashi, H. Gotoh, T. Urushima, M. Shoji, Angew. Chem. Int. Ed. 2006, 45, 958-961. DOI:10.1002/anie.200502488

15. P. Dziedzic, W. Zou, J. Háfren, A. Córdova, Org. Biomol. Chem. 2006, 4, 38-40. DOI:10.1039/B515880J

16. S. Minegishi, S. Kobayashi, H. Mayr, J. Am. Chem. Soc. 2004, 126, 5174-5181. DOI:10.1021/ja031828z

17. T. Bug, H. Mayr, J. Am. Chem. Soc. 2003, 125, 12980-12986. DOI:10.1021/ja036838e

18. T. B. Phan, M. Breugst, H. Mayr, Angew. Chem. Int. Ed. 2006, 45, 3869-3874. DOI:10.1002/anie.200600542

19. H. Mayr, J. Ammer, M. Baidya, B. Maji, T. A. Nigst, A. R. Ofial, T. Singer, J. Am. Chem. Soc. 2015, 137, 2580-2599. DOI: $10.1021 / \mathrm{ja} 511639 \mathrm{~b}$

20. T. L. Amyes, I. W. Stevens, J. P. Richard, J. Org. Chem. 1993, 58, 6057-6066. DOI:10.1021/jo00074a036

21. H. F. Schaller, H. Mayr, Angew. Chem. Int. Ed. 2008, 47, 39583961. DOI:10.1002/anie.200800354

22. R. Breslow, Acc. Chem. Res. 2004, 37, 471-478. DOI:10.1021/ar040001m

23. R. Breslow, Acc. Chem. Res. 1991, 24, 159-164. DOI:10.1021/ar00006a001

24. H. Y. Bae, C. E. Song, ACS Catal. 2015, 5, 3613-3619. DOI:10.1021/acscatal.5b00685

25. R. N. Butler, A. G. Coyne, W. J. Cunningham, E. M. Moloney, J. Org. Chem. 2013, 78, 3276-3291.

DOI:10.1021/jo400055g
26. F. C. Küpper, M. C. Feiters, B. Olofsson, T. Kaiho, S. Yanagida, M. B. Zimmermann, L. J. Carpenter, G. W. Luther III, Z. Lu, M. Jonsson, L. Kloo, L. Angew. Chem. Int. Ed. 2011, 50, 11598-11620.

27. Z. Jinjin, G. Wenchao, C. Honghong, L. Xing, L. Qiang, W. Wenlong, Chin. J. Org. Chem. 2014, 34, 1941-1957.

DOI:10.6023/cjoc201405003

28. M. Jereb, D. Vražič, M. Zupan, Tetrahedron 2011, 67, 13551387. DOI:10.1016/j.tet.2010.11.086

29. Y.-M. Ren, C. Cai, R.-C. Yang, RSC Adv. 2013, 3, 7182-7204.

30. H. Hibbert, J. Am. Chem. Soc. 1915, 37, 1748-1763.

DOI:10.1021/ja02172a015

31. G. Stavber, M. Zupan, S. Stavber, Tetrahedron Lett. 2006, 47, 8463-8466. DOI:10.1016/j.tetlet.2006.09.154

32. M. Jereb, D. Vražič, M. Zupan, Tetrahedron Lett. 2009, 50, 2347-2352. DOI:10.1016/j.tetlet.2009.02.224

33. M. Jereb, D. Vražič, M. Zupan, Acta Chim. Slov. 2009, 56, 652-658.

34. Y. Kasashima, A. Uzawa, T. Nishida, T. Mino, M. Sakamoto, T. Fujita, J. Oleo Sci. 2009, 58, 421-427.

DOI:10.5650/jos.58.421

35. Y. Ide, Y. Hori, S. Kobayashi, M. D. Hossain, T. Kitamura, Synthesis 2010, 3083-3086.

36. W. Rao, A. H. L. Tay, P. J. Goh, J. M. L. Choy, J. K. Ke, P. W. H. Chan, Tetrahedron Lett. 2008, 49, 122-126.

DOI:10.1016/j.tetlet.2007.11.005

37. M. Breugst, E. Detmar, D. von der Heiden, ACS Catal. 2016, 6, 3203-3212. DOI:10.1021/acscatal.6b00447

38. D. von der Heiden, S. Bozkus, M. Klussmann, M. Breugst, J. Org. Chem. 2017, 82, 4037-4043.

DOI:10.1021/acs.joc.7b00445

39. M. Jereb, D. Vražič, Org. Biomol. Chem. 2013, 11, 1978-1999. DOI:10.1039/c3ob27267b

40. Vogel's Textbook of Practical Organic Chemistry, Longman Group Limited: London, U. K., 1959, pp 252.

41. Y. Suh, J.-s. Lee, S. H. Kim, R. D. Rieke, J. Organomet. Chem. 2003, 684, 20-36. DOI:10.1016/S0022-328X(03)00500-X

42. E. D. Bergmann, A. M. Meyer, J. Org. Chem. 1965, 30, 28402841. DOI:10.1021/jo01019a510

43. G. V. M. Sharma, K. L. Reddy, P. S. Lakshmi, R. Ravi, A. C. Kunwar, J. Org. Chem. 2006, 71, 3967-3969.

DOI:10.1021/jo052418r

44. V. Dimitrov, S. Stanchev, B. Milenkov, T. Nikiforov, P. Demirev, Synthesis 1991, 228-232.

45. R. Stoermer, O. Kippe, Chem. Ber. 1903, 36, 3992-4013. DOI:10.1002/cber.19030360459

46. C. F. Koelsch, J. Am. Chem. Soc. 1932, 54, 2487-2493. DOI:10.1021/ja01345a046

47. I. Ho, J. G. Smith, Tetrahedron 1970, 26, 4277-4286. DOI:10.1016/S0040-4020(01)93071-6

48. D. J. Cram, D. R. Wilson, J. Am. Chem. Soc. 1963, 85, 12491257. DOI:10.1021/ja00892a009

49. Y. Sprinzak, J. Am. Chem. Soc. 1958, 80, 5449-5455. DOI:10.1021/ja01553a033

50. W. Ried, J. Schönherr, Chem. Ber. 1960, 93, 1870-1877. DOI:10.1002/cber.19600930826 
51. I. T. Badejo, R. Karaman, J. L. Fry, J. Org. Chem. 1989, 54 4591-4596. DOI:10.1021/jo00280a026

52. G.-Q. Li, Z.-Y. Yan, Y.-N. Niu, L. Y. Wu, H.-L. Wei, Y.-M. Liang, Tetrahedron: Asymmetry 2008, 19, 816-821.

DOI:10.1016/j.tetasy.2008.03.012

53. J. M. Khurana, A. Sehgal, A. Gogia, A. Manian, G. C. Maikap, J. Chem. Soc. Perkin Trans 1, 1996, 2213-2215.

DOI:10.1039/P19960002213

54. A. F. Holleman, Org. Synth., Coll. Vol. 1, 1941, 554-555.

55. M. Zupan, P. Škulj, S. Stavber, Arkivoc, 2001, 2, 108-118.

56. M. Zupan, P. Škulj, S. Stavber, Tetrahedron 2001, 57, $10027-$ 10031. DOI:10.1016/S0040-4020(01)01031-6

57. S. J. Cristol, J. R. Douglass, J. S. Meek, J. Am. Chem. Soc. 1951, 73, 816-818. DOI:10.1021/ja01146a094

58. G. Stavber, M. Zupan, M. Jereb, S. Stavber, Org. Lett. 2004, 6, 4973-4976. DOI:10.1021/ol047867c

59. R. E. Pearson, J. C. Martin, J. Am. Chem. Soc. 1963, 85, 31423146. DOI:10.1021/ja00903a021

60. C. K. Ingold, F. R. Shaw, J. Chem. Soc. 1927, 2918-2926. DOI:10.1039/JR9270002918

61. X. Zhang, W. Rao, P. W. H. Chan, Synlett 2008, 2204-2208.

62. J. S. Yadav, B. V. S. Reddy, N. Thrimurtulu, N. M. Reddy, A. R. Prasad, Tetrahedron Lett. 2008, 49, 2031-2033.

DOI:10.1016/j.tetlet.2008.01.017

63. S. Ward, T. Messier, M. Lukeman, Can. J. Chem. 2010, 88, 493-499. DOI:10.1139/V10-032

64. X. Creary, A. Wolf, J. Phys. Org. Chem. 2000, 13, 337-343. DOI:10.1002/1099-1395(200006)13:6<337::AID-POC249 $>3.0 . \mathrm{CO} ; 2-\mathrm{T}$

65. S. M. Bonesi, M. Fagnoni, Chem. Eur. J. 2010, 16, 1357213589. DOI:10.1002/chem.201001478
66. G. G. Gurzadyan, S. Steenken, Chem. Eur. J. 2001, 7, 18081815. DOI:10.1002/1521-3765(20010417)7:8<1808::AIDCHEM18080>3.0.CO;2-8

67. A. Berkessel, M. R. M. Andreae, H. Schmickler. J. Lex, Angew. Chem. Int. Ed. 2002, 41, 4481-4484.

DOI:10.1002/1521-3773(20021202)41:23<4481::AID-ANIE 4481>3.0.CO;2-7

68. J. L. Wahlstrom, R. C. Ronald, J. Org. Chem. 1998, 63, 60216022. DOI:10.1021/jo972222u

69. S. Das, R. Borah, R. R. Devi, A. J. Thakur, Synlett, 2008, $2741-$ 2762.

70. Hammett, L. P. J. Am. Chem. Soc. 1938, 59, 96-103. DOI:10.1021/ja01280a022

71. Hammett, L. P. Chem. Rev. 1935, 17, 125-136. DOI: $10.1021 / \mathrm{cr} 60056 \mathrm{a} 010$

72. M. Jereb, M. Zupan, S. Stavber, Helv. Chim. Acta, 2009, 92, 555-566. DOI:10.1002/hlca.200800308

73. K. Žmitek, M. Zupan, S. Stavber, J. Iskra, J. Org. Chem. 2007, 72, 6534-6540. DOI:10.1021/jo0708745

74. F. Goronwy Kny-Jones, A. Miles Ward, J. Chem. Soc. 1930, 535-542. DOI:10.1039/JR9300000535

75. C. Waterlot, D. Couturier, M. De Backer, B. Rigo, B. Can. J. Chem. 2000, 78, 1242-1246. DOI:10.1139/v00-082

76. K. Ramalinga, P. Vijayalakshmi, T. N. B. Kaimal, Tetrahedron Lett. 2002, 43, 879-882. DOI:10.1016/S0040-4039(01)02235-3

77. K. M. Kim, D. J. Jeon, E. K. Ryu, Synthesis 1998, 835-836.

78. G. Cavallo, P. Metrangolo, R. Milani, T. Pilati, A. Priimagi, G. Resnati, G. Terraneo, Chem. Rev. 2016, 116, 2478-2601. DOI:10.1021/acs.chemrev.5b00484

\section{Povzetek}

Preučevali smo z jodom katalizirane pretvorbe alkoholov pri reakcijskih pogojih brez topil (RPBT) in pri visoko koncentriranih pogojih (VKP) v prisotnosti različnih topil, da bi dobili vpogled v obnašanje reakcijskih intermediatov pri takšnih pogojih. Ugotovili smo, da z benzilnimi alkoholi potečejo trije različni tipi pretvorb: dimerizacija, dehidratacija in substitucija. Dimerizacija in substitucija pretežno potečeta v primeru primarnih in sekundarnih alkoholov, medtem, ko dehidratacija prevladuje v primeru terciarnih alkoholov. Relativna reaktivnost substituiranih 1-feniletanolov pri $\mathrm{z}$ jodom katalizirani dimerizaciji pri RPBT daje dobro Hammettovo korelacijo $\rho^{+}=-2.8\left(r^{2}=0.98\right)$, ki kaže na prisotnost elektronsko siromašnih intermediatov $\mathrm{z}$ določeno stopnjo razvitega naboja $\mathrm{v}$ prehodnem stanju. 